\title{
Molecular Mechanisms of Alveolar Epithelial Stem Cell Senescence and Senescence-Associated Differentiation Disorders in Pulmonary Fibrosis
}

\author{
Xiaojing Hong ${ }^{1}\left(\mathbb{D}\right.$, Lihui Wang ${ }^{1}$, Kexiong Zhang ${ }^{1}\left(\mathbb{D}\right.$, Jun Liu ${ }^{1} \mathbb{D}$ and Jun-Ping Liu ${ }^{1,2,3, *(\mathbb{D})}$ \\ 1 Institute of Ageing Research, Hangzhou Normal University School of Medicine, Hangzhou 311121, China; \\ xiaojing.hong@hznu.edu.cn (X.H.); wanglihui@hznu.edu.cn (L.W.); kxzhang@hznu.edu.cn (K.Z.); \\ junliu262@hznu.edu.cn (J.L.) \\ 2 Department of Immunology and Pathology, Monash University Faculty of Medicine, \\ Prahran, VIC 3181, Australia \\ 3 Hudson Institute of Medical Research, Monash University Department of Molecular and Translational \\ Science, Clayton, VIC 3168, Australia \\ * Correspondence: jun-ping.liu@monash.edu
}

check for updates

Citation: Hong, X.; Wang, L.; Zhang, K.; Liu, J.; Liu, J.-P. Molecular Mechanisms of Alveolar Epithelial Stem Cell Senescence and Senescence-Associated Differentiation Disorders in Pulmonary Fibrosis. Cells 2022, 11, 877. https://doi.org/ $10.3390 /$ cells 11050877

Academic Editors: Nicole Wagner and Kay-Dietrich Wagner

Received: 10 February 2022

Accepted: 2 March 2022

Published: 3 March 2022

Publisher's Note: MDPI stays neutral with regard to jurisdictional claims in published maps and institutional affiliations.

Copyright: (c) 2022 by the authors. Licensee MDPI, Basel, Switzerland. This article is an open access article distributed under the terms and conditions of the Creative Commons Attribution (CC BY) license (https:// creativecommons.org/licenses/by/ $4.0 /)$.

\begin{abstract}
Pulmonary senescence is accelerated by unresolved DNA damage response, underpinning susceptibility to pulmonary fibrosis. Recently it was reported that the SARS-Cov-2 viral infection induces acute pulmonary epithelial senescence followed by fibrosis, although the mechanism remains unclear. Here, we examine roles of alveolar epithelial stem cell senescence and senescence-associated differentiation disorders in pulmonary fibrosis, exploring the mechanisms mediating and preventing pulmonary fibrogenic crisis. Notably, the TGF- $\beta$ signalling pathway mediates alveolar epithelial stem cell senescence by mechanisms involving suppression of the telomerase reverse transcriptase gene in pulmonary fibrosis. Alternatively, telomere uncapping caused by stress-induced telomeric shelterin protein TPP1 degradation mediates DNA damage response, pulmonary senescence and fibrosis. However, targeted intervention of cellular senescence disrupts pulmonary remodelling and fibrosis by clearing senescent cells using senolytics or preventing senescence using telomere dysfunction inhibitor (TELODIN). Studies indicate that the development of senescence-associated differentiation disorders is reprogrammable and reversible by inhibiting stem cell replicative senescence in pulmonary fibrosis, providing a framework for targeted intervention of the molecular mechanisms of alveolar stem cell senescence and pulmonary fibrosis. Abbreviations: DPS, developmental programmed senescence; IPF, idiopathic pulmonary fibrosis; OIS, oncogene-induced replicative senescence; SADD, senescence-associated differentiation disorder; SALI, senescence-associated low-grade inflammation; SIPS, stress-induced premature senescence; TERC, telomerase RNA component; TERT, telomerase reverse transcriptase; TIFs, telomere dysfunction-induced foci; TIS, therapy-induced senescence; VIS, virus-induced senescence.
\end{abstract}

Keywords: replicative senescence; DNA damage response; telomerase and telomeres; TGF- $\beta$ signalling; pulmonary fibrosis; COVID-19

\section{Introduction}

Ageing, characterized by the gradual loss of the integrity of the body's physiological function over time, occurs at a different pace as different tissue stem cells experience different stress pressures and damage accumulations. In the lung, pulmonary epithelial senescence represents the highest risk of idiopathic pulmonary fibrosis (IPF) [1,2]. Recently it was reported that SARS-Cov-2 viruses cause acute pulmonary virus-induced senescence (VIS), and subsequently fibrosis, illustrating a major mechanism of coronavirus disease 2019 (COVID-19) [3-5]. VIS features not only alveolar stem cell exhaustion, but also epithelial sloughing, dishevelled repair and fibrogenesis, ultimately resulting in recurrent 
dyspnea and respiratory failure similar to IPF [1,3-8]. As the alveolar epithelia contain predominantly alveolar monolayer squamous epithelial type 1 (AEC1) cells $(80 \%)$ that are terminally differentiated without replicative capacity and the round cubic AEC2 stem cells $(\sim 15 \%)$ undertaking self-renewal, proliferation and differentiation to ACE1 $[9,10]$, VIS exemplifies an acutely accelerated form of alveolar senescence in the wake of the cell cycle arrest [3]. However, the mechanism of the accelerated cellular replicative senescence remains to be elucidated in association with widespread alveolar epithelial interstitial damages, epithelial cell repair failure, myofibroblast fibrogenic proliferation and extracellular matrix deposition [3-5].

Differing from such pulmonary stem cells at the distal end of the bronchus as the clublike stem cells [11], distal airway stem cells (DASC) [11,12] and bronchioalveolar stem cells (BASC) [13], AEC2 stem cells reside within the alveolar epithelium with a significant heterogeneity with variable levels of the marker CD44, telomerase activity, and proliferative and differentiation potentials in response to a variety of cellular signalling in ageing $[14,15]$. Whereas chemically defined EGF/NOGGIN medium supports the basal proliferation of clonal AEC2 cells in the organoids [16], potentially through a constitutive activity of the single Wnt5a-signalling stromal fibroblast niche, an injury-associated activation of AEC2 stem cell expansion involves autocrine Wnt signalling associated with a potential checkpoint regulation in lieu of the niche juxtacrine Wnt signalling [17]. Responding to a transient interstitial macrophage-derived IL-1beta, the AEC2 stem cell population undergoes a reshuffle of a distinct subpopulation (damage-associated transient progenitors, DATPs) expressing Il1r1 for alveolar regeneration via a HIF1alpha-mediated glycolysis pathway [18]. However, in contrast to a full differentiation to AEC1 cells $[16,18,19]$, AEC2 cell differentiation to AEC1 cells is hampered at an intermediate, partially differentiated status of AEC2 stem cells (called pre-alveolar type-1 transitional cell state, PATS or alveolar differentiation intermediate, ADI) under persistent inflammatory stress conditions, showing cellular replicative senescence in pulmonary fibrosis of both animal models and patients [4,18-23]. These findings of AEC2 stem cell senescence-associated differentiation disorder (SADD) may have significant implications in not only the impaired AEC1 cell replenishment during alveolar epithelial repair, but also aberrant trans-differentiation during the pathogenic development of pulmonary fibrosis (Figure 1).

Cellular replicative senescence occurs in various forms depending on the mechanisms leading to replicative senescence. Such forms have been described as stress-induced premature senescence (SIPS), oncogene-induced replicative senescence (OIS), developmental programmed senescence (DPS) and therapy-induced senescence (TIS), which display a general underlying mechanism of the permanent cell cycle arrest in cellular mitotic divisions. Initially referred to as the irreversible cell proliferation ability after a limited number of continuous population doublings for human diploid fibroblasts (HDFs), cell senescence occurs as a general feature of the different types of cell replicative senescence to the resistance to both cell proliferation and cell death signalling, e.g., without responding of mitosis to growth factor induction $[24,25]$. Thus, the primary cellular mechanism of cell replicative senescence converges on the cell cycle permanent arrest provoked by significant stress insults along with sustained DNA damage in response to a variety of physical, chemical and biological stimuli (Figure 1). Although a variety of diverse stressors accelerate premature terminations of the cell cycle, including chemical toxins, antibiotics and oxidative stress in the airways [24,26-29], cell replicative senescence appears irreversible as demonstrated in SIPS and OIS [30]. With the enhanced mitogenic signalling such as activation of the Ras/MAPK pathway, and the epigenetic modifications such as histone-3 lysine-9 trimethylation (H3K9Me3) in the senescence-associated heterochromatin foci [30,31], OIS occurs to serve as an oncogenic checkpoint to prevent tumor cell clonal expansion and micro-evolutionary transformation with increased oncogenic proteins (such as c-myc [32] and mTOR [33]). In contrast to OIS, SIPS and VIS occur with excessive damages to serve as a proliferative and differentiative checkpoint to prevent cellular damage from passing onto daughter cells $[3,34,35]$. However, it remains unclear how the cell cycle arrest is specifically 
regulated in SIPS, OIS and VIS. Previous studies suggest that cellular replicative senescence involves the activation of retinoblastoma protein (RB) signal transduction pathways of tumor suppressor genes $p 53-p 21^{C I P 1} / C D K N 1 A$ and $p 16^{I N K 4 A} / C D K N 2 A[3,36-38]$. Additionally, DPS may occur via the transforming growth factor- $\beta$ (TGF- $\beta$ ), PI3K and ERK1/2 pathways to regulate tissue remodelling [39]. Moreover, the ER unfolded protein response $\left(E R^{U P R}\right)$ may participate in TIS with increased ER associated degradation (ERAD), resulting in ER-related senescence-associated apoptosis in a caspase-12 and caspase-3 dependent manner [40]. While it remains unclear if ER-mediated TIS entails DNA damage response (DDR), recent studies show that TIS reprograms cancerous cells to acquire the cellular phenotypic features of cellular stemness [41].

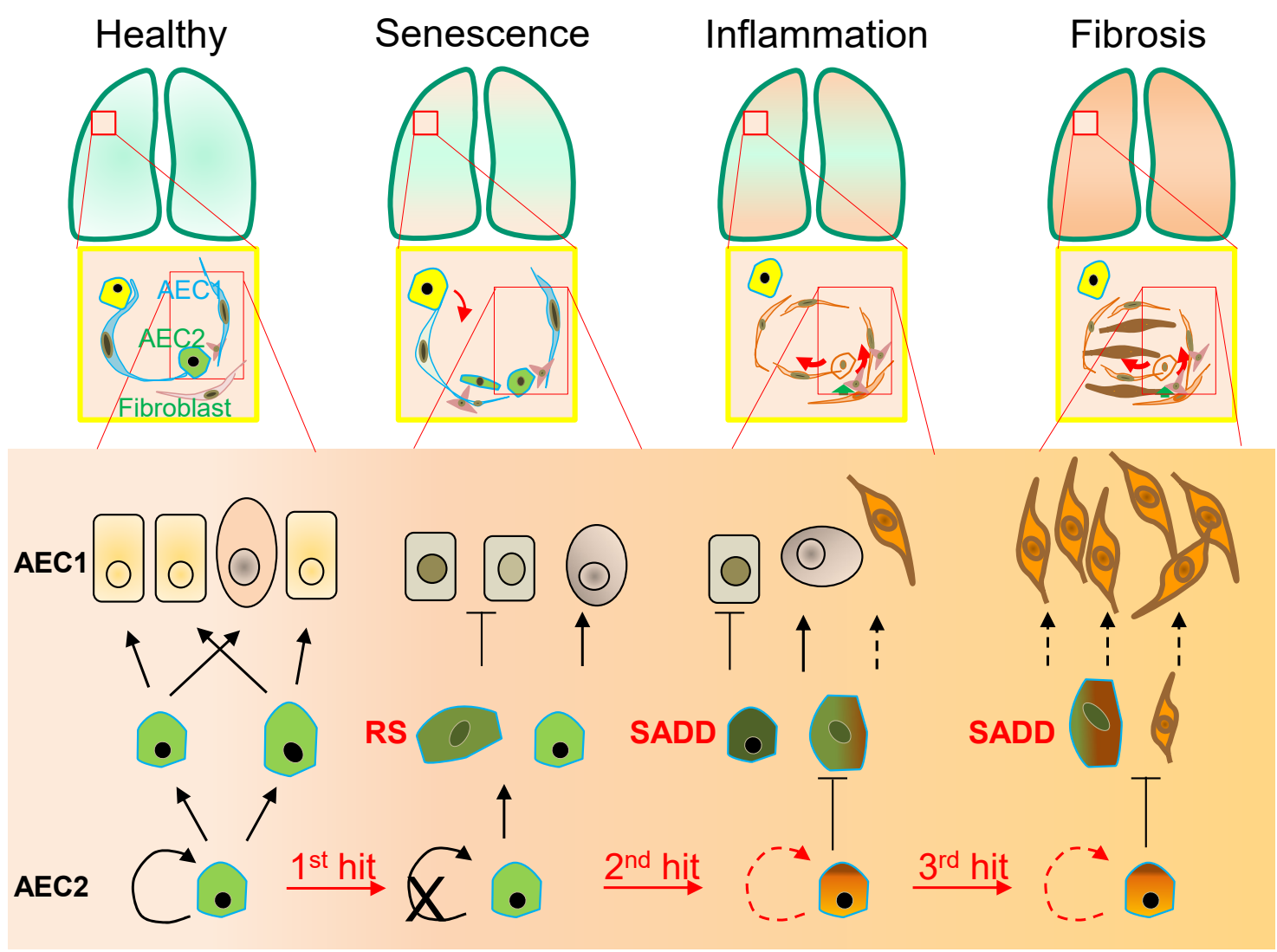

Figure 1. Alveolar monolayer squamous epithelial type 2 (AEC2) stem cell differentiation arrest and transdifferentiation disorder in pulmonary fibrosis. During pulmonary fibrogenesis, AEC2 stem cells are susceptible to stress assaults triggering telomeric DNA damage response (DDR) and replicative senescence and senescence-associated cease of the directional differentiation to alveolar monolayer squamous epithelial type 1 (AEC1) cells. Chronic stress induces senescent AEC2 stem cells to undergo transdifferentiation. The senescence-associated differentiation disorders (SADDs) contribute to myofibroblast proliferation under the condition of senescence-associated low grade inflammation (SALI).

Intriguingly, the intrinsic reprograming mechanism of a potential cell transition from ceasing replication to entering senescence may involve the transcriptional repression of the telomerase reverse transcriptase (TERT) gene expression, conferring cell replicative senescence on oncogene-stimulated cell division [42]. Additionally, TP53 phosphorylation at S15 residue [38] and TP53 fluctuation in oscillatory dynamics [43] may also be involved in the pathway switching from cell replicative senescence to a cell proliferative state. Furthermore, DNA methylation of the Oct4A enhancers may regulate the TP53-dependent TIS through tuning alternative splicing [44]. With an instrumental non-cell-autonomous role of SASP $[41,45,46]$, cell replicative senescence plasticity represents a hotspot of further inves- 
tigation in terms of autocrine/juxtacrine/paracrine actions of growth factors, proteases, cytokines, chemokines and extracellular matrix (ECM) components [47-51]. In this regard, studies showed that the extracellular vesicles (EVs)—exosomes, ectosomes, microvessels and microparticles-are increased in cell replicative senescence responding to ionizing radiation, chemical reagents or overexpression of oncogenes in a number of cell types including epithelial cells [52,53], and that TP53 activation increases EV release and mediates prostate cancer cell senescence induced by telomere shortening or radiation [53], suggesting that extracellular vesicular signalling represents a potential mechanism shaping cellular responses to and from replicative senescence. In the following sections, we focus on the phenotypic characteristics of SADD in the development of pathological fibrogenic remodelling and explore the molecular mechanisms mediating telomere maintenance, homeostatic disruption and prophylactic/therapeutic interventions as well in stress-induced cell replicative senescence and pulmonary fibrosis.

\section{Senescence-Associated Differentiation Disorder (SADD)}

As the lung peripheral tissue stem cells that are essentially required for alveolar epithelial damage repair and regeneration [10-13], AEC2 stem cells are compromised in replenishing AEC1 cells in pulmonary fibrosis [23,54,55]. In a long-term process of AEC2 cell self-renewal and directional differentiation to form AEC1 cells by pedigree tracing [10], AEC2 cells respond to chronic stress with the phenotypes of permanent termination of the cell cycle and differentiation to AEC1 [9,18,19,22] by an unclear molecular mechanism [18-23]. In the case of diffuse alveolar damage, in addition to discontinued differentiation to AEC1 cells, AEC2 stem cells arrested at $\mathrm{G}_{2} / \mathrm{M}$ of the cell cycle can express a high level of KRT8, and exhibit the cubic and partial spreading morphologies [18-21,23,56,57]. Moreover, the AEC2 senescent cells appeared to be undergoing a program of transdifferentiation to a mesenchymal state in association with increased levels of $\alpha$-SMA and collagen [35,58-63]. Collectively, these studies implicate AEC2 senescent stem cells as behaving with a SADD characteristic of the loss of differentiation to AEC1 cells and the gain of aberrant transdifferentiation during pulmonary pathogenic fibrogenesis. The features of stress-induced AEC2 stem cell replicative senescence and SADD in mice are consistent with recent clinical findings that AEC2 stem cells express increased senescence markers, including $\mathrm{p} 16^{\mathrm{INK} 4 \mathrm{~A}} / \mathrm{CDKN} 2 \mathrm{~A}$, p14 $4^{\mathrm{INK} 4 \mathrm{~B}} / \mathrm{CDKN} 2 \mathrm{~B}, \mathrm{TP} 53$ and p21 ${ }^{\mathrm{CIP} 1} / \mathrm{CDKN} 1 \mathrm{~A}[3,4,7]$, and that AEC2 stem cell SADD existed throughout the course studied in the pneumonia-induced acute respiratory distress syndrome and pulmonary fibrogenesis $[4,64,65]$. Importantly, AEC2 stem cell SADD manifested in association with pulmonary interstitial deposition in both COVID-19 [64] and IPF [66]. It is thereby probable that AEC2 stem cell replicative senescence mediates the differentiation failure of AEC 2 stem cell replenishing damaged AEC1 cells by a mechanism at least involving the compromised proliferative potential [3]. Inducing AEC2 stem cell senescence or otherwise depletion demonstrated that AEC2 senescence, rather than AEC2 cell loss, promotes progressive fibrosis [38], consistent with a gain of malfunction of senescent AEC2 cells as a mechanism in causing pathogenic fibrogenesis. Moreover, preventing AEC2 stem cells from entering replicative senescence [35], or eliminating replicative senescence cells in COVID-19 [3], rescues pulmonary fibrosis in the animal models, underscoring that AEC2 stem cell replicative senescence is a prerequisite driver of pulmonary fibrosis [38].The mechanism of AEC2 stem cell SADD remains to be investigated extensively, although dysregulation of several intracellular signalling pathways (including the TGF- $\beta$ family) participates in the deregulation of AEC2 differentiation $[19,67]$. Notably, serving as a regulatory switch, BMP4 was reported to inhibit AEC2 stem cell proliferation while stimulating AEC2 stem cell differentiation to AEC1 cells [67]. Conversely, the antagonists, follistatin and noggin, promote $\mathrm{AEC} 2$ stem cell self-renewal and inhibit AEC2 stem cell differentiation to AEC1 cells [67]. Moreover, a number of other extracellular factors including TGF- $\beta$, TGF- $\alpha$, IL-13, TNF- $\alpha$, IL-1 $\beta$, IL-1R1, retinoic acid and platelet-derived growth factor are likewise implicated in shutting down AEC2-to-AEC1 cell differentiation in the milieu of the alveolar interstitium $[18,68,69]$. It is suggested that TGF- $\beta$ and follistatin-like 1 form 
a positive feedback loop in accelerating the pathogenic differentiation of fibrogenesis in IPF [70]. While the downstream effectors of TGF- $\beta$ may engage in regulating the telomerase TERT gene and telomere maintenance negatively, it has been shown recently that protecting telomeres from dysfunction eliminates stress-induced AEC2 stem cell senescence and subsequent pulmonary fibrosis (see below for details).

In addition to the discontinued AEC2-to-AEC1 cell differentiation in SADD of IPF, AEC2 cell transdifferentiation in the pathological fibrogenic condition [35,58-63] may involve epithelial-mesenchymal transition (EMT) [62,63,71-76]. Evidence of AEC2 cell contributing to fibrogenesis via transdifferentiation includes co-localization of SPC with $\alpha$-SMA, Col1 $\alpha 1$ and hydroxyproline in the mouse models of pulmonary fibrosis [35,61-63]. In addition, recent single-cell RNA sequencing studies revealed that a cell population of replicative senescence is associated with transdifferentiation in the profiles of KRT5 ${ }^{-} / \mathrm{KRT}^{-} 7^{+}$marks and increased gene expressions of a subset of mesenchymal genes such as Col1 $\alpha 1$ in the fibrotic lung of patients [56,57]. Lineage-tracing studies in mice show that AEC2 stem cells undergo aberrant cellular remodeling with stretching morphological alterations in association with replicative senescence characteristic of SADD, by a mechanism involving increased TGF- $\beta$ and TP53 signaling $[19,38,77]$. Thus, it is conceivable that SADD underlies the discontinuation of AEC2 stem cell differentiation to AEC1 cells and initiations of myofibroblast activation and matrix deposition under the conditions of alveolar senescenceassociated low-grade inflammation (SALI) [78-81] with inflammatory cell and cytokine signaling $[19,62,63,71-76,82,83]$. Further studies are required to investigate if cell replicative senescence may dictate SADD through intracellular mechanisms prior to SALI (Figure 2), so inhibiting cell replicative senescence may impede SADD as to prevent fibrogenesis in the animal models of telomere dysfunction-induced pulmonary fibrosis [35].

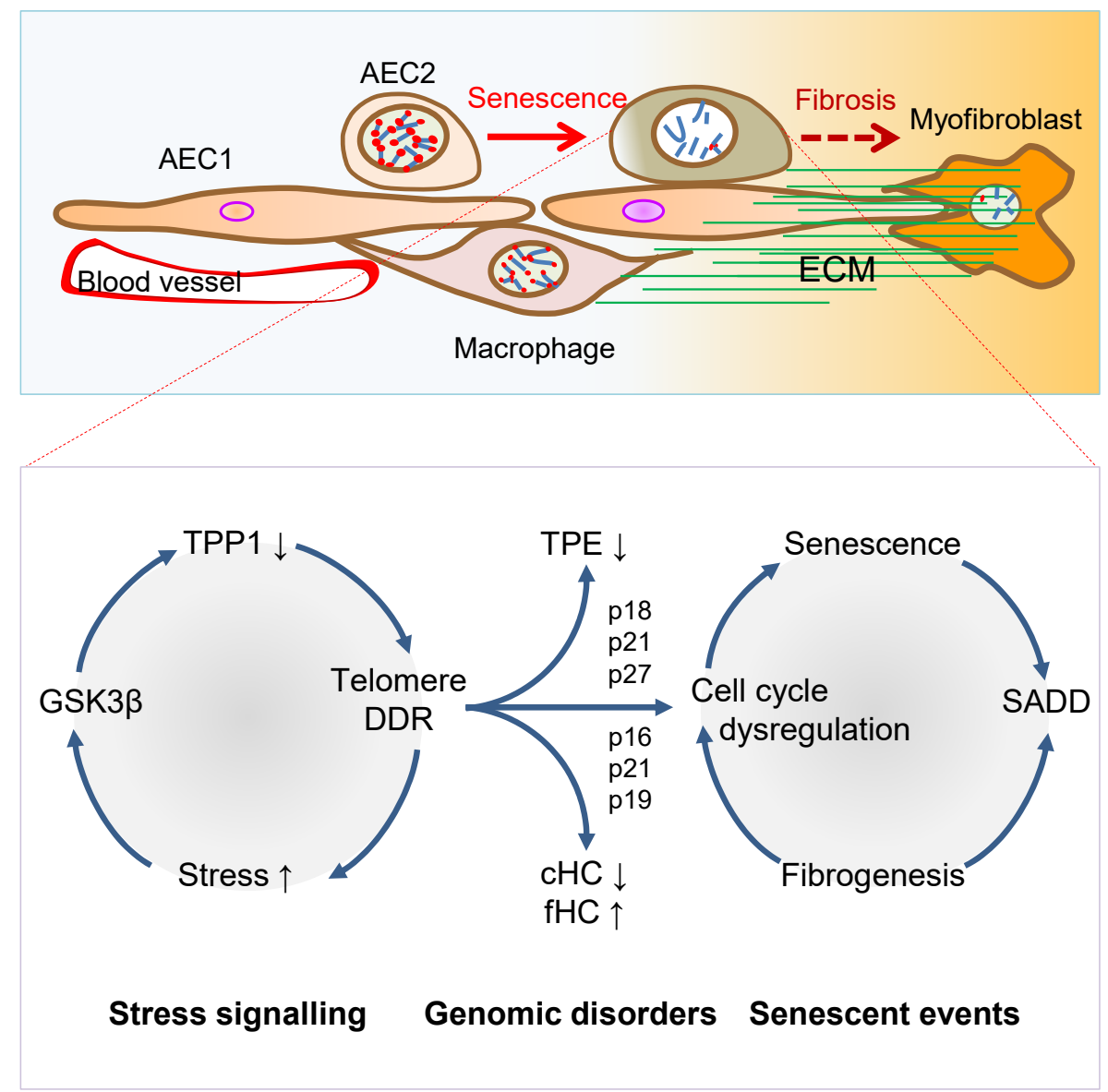

Figure 2. Mechanisms of AEC2 stem cell senescence and SADD. Cellular stress signalling triggers GSK3 $\beta$ targeting of telomere shelterin complex, inducing the telomerase recruitment protein TPP1 phosphorylation, 
subjecting phosphorylated TPP1 multisite polyubiquitination and degradation, resulting in telomere uncapping. The telomere uncapping triggers telomeric DDR, resulting in activation of the cyclindependent protein kinase inhibitors and cell cycle deregulation through telomere position effect (TPE) and altered constitutive and facultative heterochromatins ( $\mathrm{cHC}$ and $\mathrm{fHC}$ ). Unresolved telomeric DNA repair and cell cycle arrest result in stem cell senescence and subsequent SADD including differentiation arrest and trans-differentiation underlying pulmonary fibrosis.

\section{Telomere Dysfunction Mediates Pulmonary Senescence and Fibrosis}

AEC2 stem cell replicative senescence has been shown to involve DDR in SADD and IPF [35,84-87] under SALI, which is subserved by senescence-associated secretory phenotype (SASP) and infiltrations of inflammatory and immune cells [78-81] (Figures 1 and 2). Genetically, loss of function mutations of the genes encoding TERT, telomerase RNA component (TERC), poly-(A)-specific ribonuclease (PARN) and regulator of telomere length 1 (RTEL1) underpins patient familial recessive hereditary IPF $[2,18,88-93]$. Notably, over a third of IPF cases with hereditary susceptibility of autosomal recessive gene damages could be related to telomere-related gene mutations including telomerase catalytic subunit TERT and RNA subunit TERC genes [6,35,93-97], and some could be related to mutations of the genes coding SPC or SPA of alveolar stem cells [98-100]. With the hypothesis that genetic susceptibility involves vulnerable genetic elements such as telomeres predisposing increased pulmonary sensitivity to environmental hazard-accelerated damages [35], it has been shown that stress-induced DDR occurs rapidly to telomeres, in a more abundant scale in telomeres as compared with non-telomeric regions in the genome [35,101,102]. The telomeric DDR takes place irrespective of telomerase activity, resistant to DNA repair, rendering irreparable DDR to be persistent in causing cellular replicative senescence [103-106]. Thus, preventing stress-induced telomere damages may protect the cells from entering replicative senescence and fibrogenesis.

Environmental factors triggering pulmonary senescence and fibrotic disease onset have been a hot topic in aiming to prevent the incurable disease IPF without yet effective therapy [91,96]. Since the 1980s, environmental stress factors that drive pulmonary fibrotic onset include smoking, bacterial toxin bleomycin [107,108], ionizing radiation (IR) [109-111], and oxidative metabolite reactive oxygen species [84,112-115]. Such environmental stress cues as bleomycin $[58,116,117]$, IR $[105,118,119]$ or $\mathrm{H}_{2} \mathrm{O}_{2}[102,120-122]$ have been shown to induce telomere DNA damage, resulting in telomere shortening. Consistent with cigarette smoking as causing pulmonary lesions by a mechanism of telomeric DDR [123-125], a significant number of smokers with IPF and chronic obstructive pulmonary disease (COPD) demonstrated acceleratory shortening of telomeres $[47,123,126]$. We demonstrated that radiation exposure, oxidative stress (such as $\mathrm{H}_{2} \mathrm{O}_{2}$ ) or bacterial product bleomycin each trigger telomere shelterin protein TPP1 degradation in AEC2 stem cells, provoking telomere uncapping, DDR, stem cell exhaustion, fibrogenic gene expressions, and pulmonary fibrosis [35]. These findings indicate a primary mechanism through which environmental stress induces AEC1 cell damage and coerces AEC2 stem cells to succumb to replicative senescence and SADD in pulmonary fibrosis.

In the telomere syndrome traits, IPF appeared more common than bone marrow diseases [58,95,127] (such as aplastic anemia [128] or dyskeratosis congenita (DC) [129-132]). The incidence of IPF is related to the aggravation of lung epithelial injuries, alveolar stem cell replicative senescence and SADD induced by environmental stress factors such as smoking, infection, radiation injury, oxidative stress [16,35,93,117]. It is thought that once in replicative senescence, AEC2 stem cells are entangled in the milieu of SALI in relaying bidirectional signal transductions via a variety of inflammatory factors to and from senescent cells, thereby driving the development of fibrogenesis [78,133-135]. Animal studies have demonstrated that environmental stresses, such as viral infection, induce extensive inflammatory responses, interstitial hyperplasia and edema of the lung tissue, resulting in fibrosis and dyspnea $[35,136,137]$, characteristic of chronic pulmonary epithelial reduction, 
diffuse alveolitis and interstitial myofibroblast proliferation [78,138]. Investigation of the key molecular mechanisms mediating stress-induced pulmonary cellular senescence may unveil molecular targets pivotal for intervention in pulmonary fibrosis as in IPF. What remains unclear for decades includes how telomere shortening or replicative senescence is triggered and accelerated to provoke IPF by various environmental stressors. Telomeres are composed of the DNA repeats, (TTAGGG) ${ }_{n}$, and their binding protein complex shelterin at chromosome ends, underpinning chromosome integrity and stability in the regulation of genome homeostasis in cell development, proliferation and differentiation [139-142]. Shelterin contains six proteins, telomere repeat binding factor 1 (TRF1), TRF2, RAP1, TIN2, POT1 and TPP1, and covers both double-stranded and single-stranded telomeric DNA, preventing telomeres from inadvertently activating DDR and replicative senescence in stress responses $[143,144]$. Under physiological conditions, telomere maintenance, or shortening as it occurs with cell replication, is regulated by the levels of shelterin and operates as the mitotic clock that results in their exit from the cell cycle in replicative senescence $[145,146]$. However, telomere dysfunction occurs as a function of sustained abundance of environmental stress stimulations, preceding non-telomeric DNA damages which ensue to telomere dysfunction [35]. Critical stress pressures [6,35,119,147,148], and chronic insufficiency of telomeric DNA repair, such as repressions of telomerase genes, repressions $[35,78,149,150]$, together result in telomere shortening, ultimately premature senescence, and ageing-related diseases. Telomere dysfunction as a potential cause of ageing-related diseases $[127,151,152]$ results from mutations of telomere related genes, including those encoding shelterin proteins [143], and telomerase [78,153].

Shelterin and telomerase function to protect telomeres by preventing cells from telomere DDR $[29,154-157]$ and entering senescence $[27,28,78,152,153]$. Genetic mutagenesis of TRF2 or telomerase genes induces pulmonary fibrosis [58,78], whereas transgenically expressing TERT holds a therapeutic potential in alleviating pulmonary fibrosis [158]. In addition, the $A C D$ gene coding for TPP1, which caps the telomere ends and recruits telomerase [159-165], was associated with such stem cell diseases as aplastic anemia with bone marrow failure [166] and Hoyeraal-Hreidarsson syndrome [167], and the expression levels of TPP1 were significantly reduced in the lung tissue of patients with chronic obstructive pulmonary disease (COPD) [168]. These studies suggest that qualitative and quantitative alterations in telomere shelterin and telomerase components accelerate telomere shortening, stem cell replicative senescence and related disorders.

\subsection{Telomerase Gene Deficiency in Ageing-Related Disorders}

Telomerase replenishes telomeres to counteract shortening by TERC template reverse transcription $[169,170]$. Telomerase catalytic subunit TERT determines telomerase activity in lengthening telomeres, conferring the ability of continuous proliferation and survival on stem cells and tissue precursor cells [171-176]. In addition to elongating telomeres, TERT is involved in maintaining telomere heterochromatin and synthesizing double-stranded RNA through RNA-dependent RNA polymerase activity (RdRP) [177-179]. Telomerase deficiency due to TERT mutations results in stem cell replicative senescence and exhaustion, tissue fibrosis, aplastic anemia, and skin diseases of premature ageing [35,78,132,180,181]. While TERT gene expressions are fundamental to telomerase activity and stem cell renewal, tissue regeneration, the molecular mechanisms underlying TERT gene expression remain largely elusive [182]. Multiple lines of evidence indicate that several transcription factors play fundamental roles in regulating TERT transcription [183] (Figures 3 and 4). Our laboratory established for the first time that downstream MAP kinase signalling [184], ETS transcription factors bind to the TERT gene promoter ETS binding motif (CCTT) directly, functioning as an essentially key transcription factor for TERT gene expression in cancer $[184,185]$. Moreover, ETS activates TERT transcription not only directly by binding to the CCTT element and in cooperation with the proto-oncogene c-myc that binds to the E-box (CACGTG) at the TERT promoter in the regulation of telomerase activity and cell proliferation [185-188] (Figures 3 and 4). The role of ETS in TERT gene expression has been 
confirmed independently in cancer patients with $\mathrm{C} \rightarrow \mathrm{T}$ nucleotide mutations creating additional ETS binding sites [189,190] and mechanistically [191]. Furthermore, Wu et al. showed first that c-myc activates TERT by binding to the E-box at the TERT gene promoter [192]. However, the action of c-myc at the E-box of TERT promoter is regulated negatively by Max/Mad1 interaction [193] and by TGF- $\beta$ signalling via Smad3 interactions with c-myc and the TERT gene promoter [186,188] (Figures 3 and 4). Our laboratory demonstrated that estrogen upregulates TERT gene expression and telomerase activity in the endocrine organs of ovary and adrenal gland for tissue homeostasis [149,150,194,195]. Deficiency of estrogen in mice by targeted disruption of the aromatase gene responsible for estrogen synthesis results in compromised cell proliferation and stem cell exhaustion [149,150]. Interestingly, hormone replacement therapy increases the activities of telomerase and stem cell renewal positive for Ki67 staining and the stem cell markers stem-cell antigen-1 (Sca-1) and c-kit expression, attenuating premature ageing and tissue atrophy at both adrenal and ovarian glands $[149,150]$. These studies are consistent with the current notion that telomerase TERT is required for the maintenance of telomeres and stem cell functionalities in the endocrine, epithelial and endothelial tissues against tissue degenerative changes and proliferative disorders [196-198].

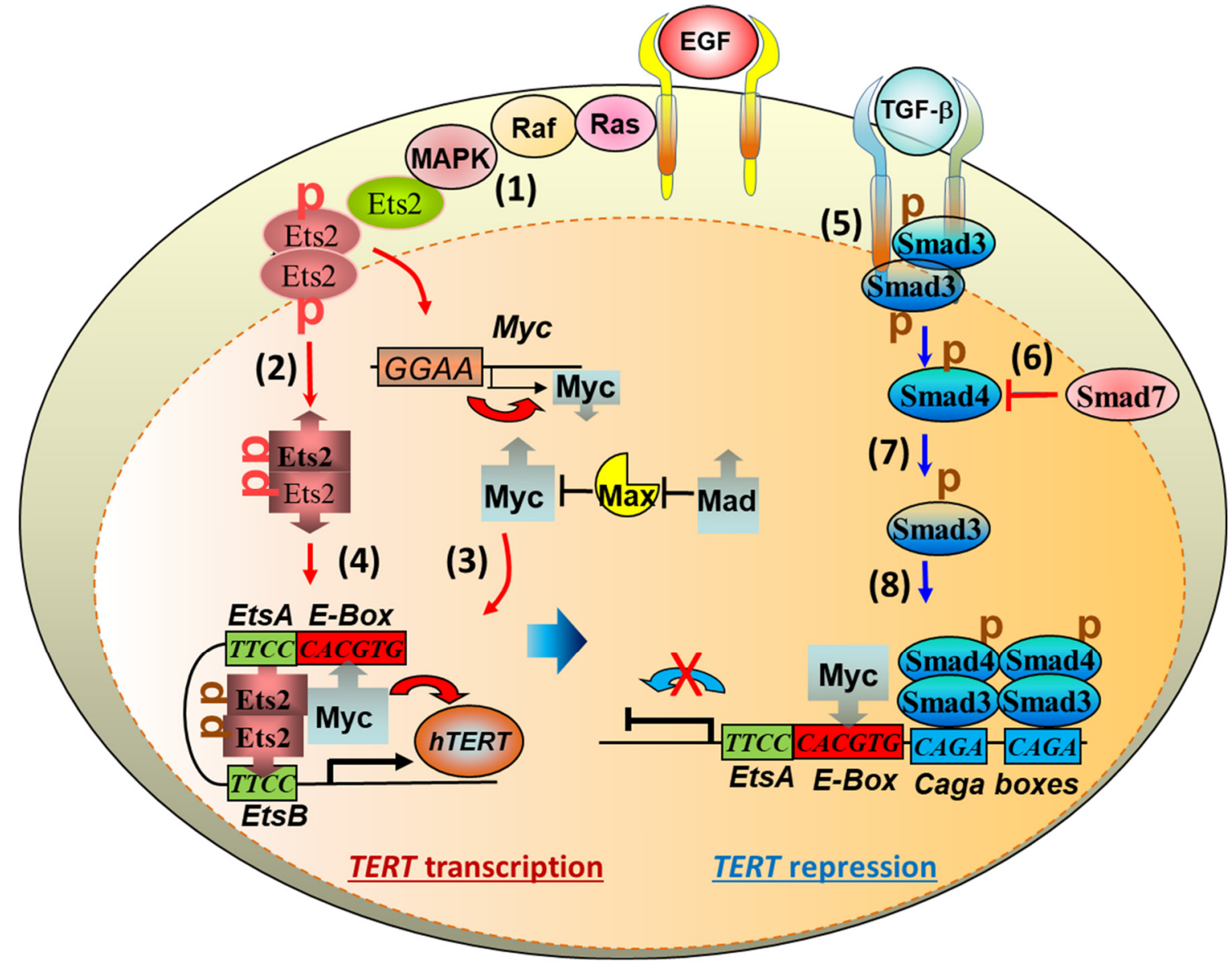

Figure 3. Intracellular signalling pathways of growth factors to the transcription factors and repressors in the regulation of telomerase reverse transcriptase (TERT) gene transcription. The TERT gene promoter assumes both active and repressive conformations under the molecular regulation of the MAP kinase and TGF- $\beta$ signalling pathways, respectively. Epithelial growth factor (EGF) stimulated mitogenic signalling induces MAP kinase-mediated Ets2 transcription factor phosphorylation, nuclear retentions and dimerisation (1-2). Ets2 binds the CCTT element in the TERT and c-myc gene promoters, driving c-myc (3) and TERT (4) transcriptions in the upregulation of cell proliferative immortality. On the other hand, TGF- $\beta$ activates TGF- $\beta$ RII receptors by auto- and trans-phosphorylation, resulting in Smad3 phosphorylation and mobilization (5), which is regulated 
natively by Smad7 (6) and positively by Smad4 (7) in the Smad3 nuclear localization and action. Smad3 binds to the CAGA element in the TERT promoter to repress TERT gene transcription in pathological fibrogenesis such as pulmonary fibrosis (8).

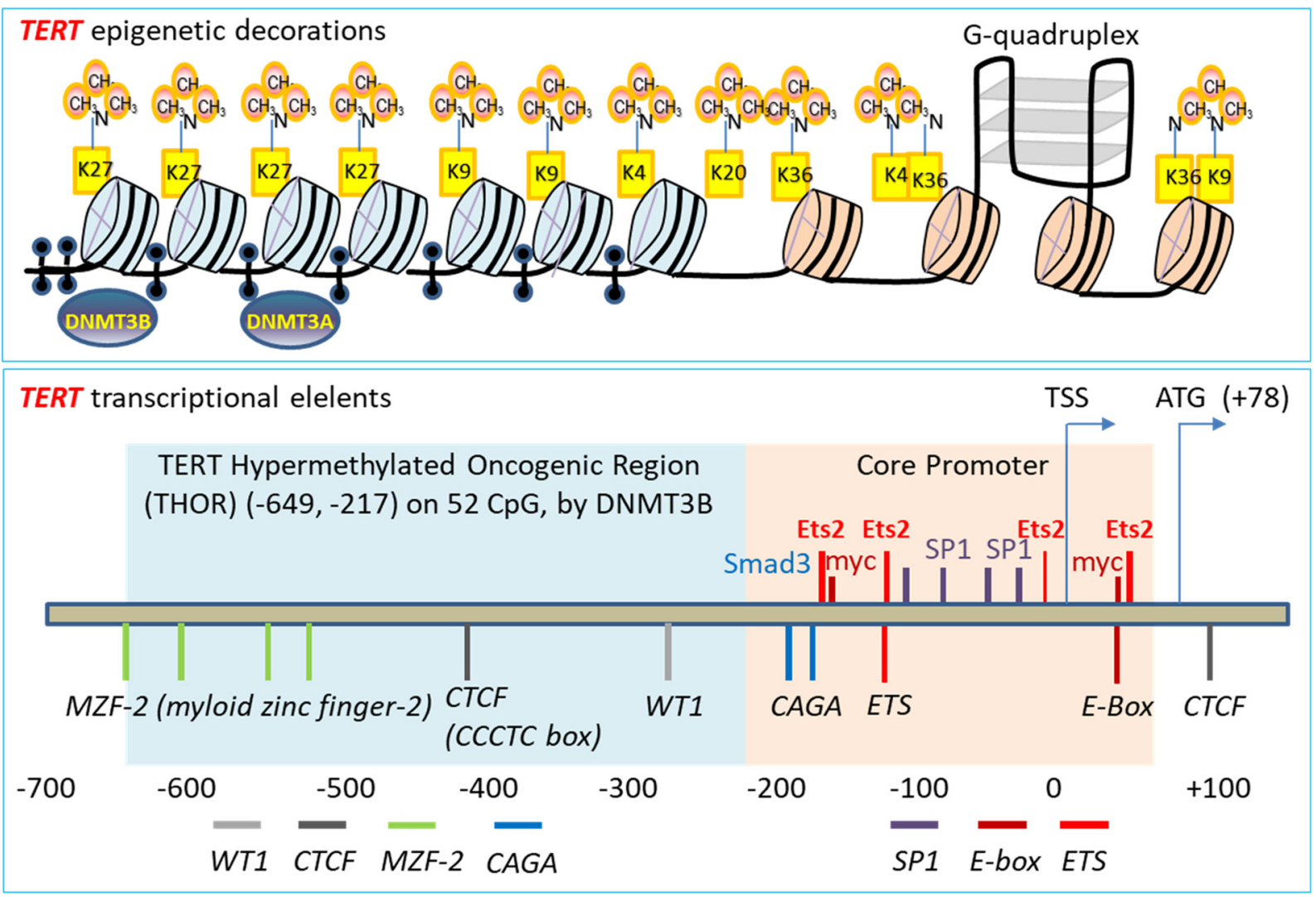

Figure 4. The regulatory network of TERT gene transcription. Top panel: Epigenetic regulatory organization of the TERT gene promoter repression involves trimethylation of the various lysine residues $(\mathrm{K})$ on the nucleosome histone tails, methylation of $\mathrm{C} 5$ cytosine of $\mathrm{CPG}$ dinucleotides by DNA methyltransferase 3 alpha and beta (DNMT3A and 3B), and G-quadruplex. Bottom panel: TERT promoter DNA regulatory elements (italic), and engaged transcription factors and repressors (non-italic) in the positive (red) and negative (blue) regulations of TERT gene transcription. The scale labelled is for relative positions of promoter upstream regulatory DNA elements, but not in proportion.

\subsection{TGF- $\beta$ Signaling to Telomerase TERT Gene Repression}

TGF- $\beta$ signaling is closely involved in pulmonary fibrosis $[19,20,22,23,56,57,82,199-201]$. The mechanisms of how TGF- $\beta$ family cytokines regulate the intracellular events mediating pulmonary fibrogenesis remain unclear [202]. Studies indicate that mediating the interactions between AEC2 stem cells and fibroblasts, TGF- $\beta$ released from cells [203] induces Sonic Hedgehog (SHH) pathway in alveolar epithelial cells by autocrine mechanisms, whereas $\mathrm{SHH}$ induces TGF- $\beta$ in lung fibroblasts stimulating myofibrosis by paracrine mechanisms, suggesting that re-emergence of SHH in epithelial cells mediates TGF- $\beta$ signaling and induces myofibroblast differentiation in a Smoothened receptor-dependent manner with subsequent transcription factor Gli1 activation of the $\alpha$-SMA promoter [204]. In addition, elevated extracellular mechanical tension between myoblasts and AEC2 stem cells activates TGF- $\beta$ RII receptor signaling in AEC2 stem cells, resulting in AEC2 stem cells with increased TGF- $\beta 1$ and becoming gradually unable to differentiate to AEC1 cells [23]. Deletion of the TGF- $\beta$ RII receptor specifically in lung epithelium protects mice from bleomycin-induced pulmonary fibrosis, further supporting a central role TGF- $\beta$ signaling 
of alveolar epithelium in fibrogenesis [82,205]. Reflecting SADD, moreover, recent studies show that in radiation-induced pulmonary fibrosis, both TGF- $\beta$ and GSK3 $\beta$ are increased in AEC2 cells undergoing transdifferentiation with increased AEC1 cells and mesenchymal markers such as $\alpha$-SMA [206]. These studies suggest that TGF- $\beta$ in the intercellular milieu stimulates AEC2 cell transdifferentiation by mechanisms involving GSK3 $\beta$ in association with SHH cellular signaling.

The mechanism of intracellular transduction initiated by TGF- $\beta$ in the induction of pulmonary fibrosis entails receptor-mediated Smad3 signaling. Firstly, epithelium-specific disruption of TGF- $\beta$ RII receptor increases Smad2 phosphorylation and decreases Smad3 phosphorylation, and protects mice from bleomycin-induced pulmonary fibrosis with increased survival [82] (Figure 3). In addition, knockout of Smad3 [207], or inhibition of phosphorylated Smad3 into the nucleus by polypeptide [208], inhibits TGF- $\beta 1$-induced pulmonary fibrosis in mice. Moreover, in an attempt to determine the downstream mechanisms of TGF- $\beta$ activation of Smad3 co-transcription factor, our laboratory demonstrated that by acting on different specific RII receptors, TGF- $\beta 1$ induces Smad 3 translocation from the cytoplasm to the nucleus where Smad3 binds the CAGA box in the TERT gene promoter interfering c-myc binding and repressing TERT transcription [188,209-211] (Figures 3 and 4). Furthermore, the TGF- $\beta$ family member BMP7 induces the TERT gene repression in a BMP RII receptor- and Smad3-dependent manner [211,212]. Chronic exposure to BMP7 results in telomere shortening, cell replicative senescence and apoptosis, but mutation of the BMP RII receptor (but not TGFbRII, ACTRIIA or ACTRIIB receptors) inhibits BMP7-induced TERT repression, leading to increased telomerase activity, lengthened telomeres and continued cell proliferation [211]. The effect of BMP7-induced cell replicative senescence and apoptosis is TERT repression-dependent as overexpression of TERT reverses BMP7-induced cell replicative senescence [211]. These data together suggest that Smad3-mediated repression of the TERT gene and shortening of telomeres are critical to TGF- $\beta$ induced pulmonary senescence, SADD, and pathological fibrogenesis.

\subsection{Stress-Induced TPP1 Degradation and Telomere Uncapping}

In the regulation of telomerase lengthening of telomeres, recruiting telomerase to telomeres represents a most effective step in telomere maintenance. Our recent studies show an intertwined relationship of TPP1 capping of telomeres, recruitment of telomerase, deficiency-induced telomere uncapping, pulmonary senescence, and fibrosis [35,213]. By targeted protection of telomere uncapping, we demonstrate that pulmonary senescence and fibrosis with dyspnea are altogether prevented in mice under persistent fibrogenic stresses including whole body ionizing radiation or pulmonary bacterial toxin bleomycin [35]. The stress-induced pulmonary senescence and fibrotic onset are targetable through animal inhalation of either recombinant cDNA coding for the telomere protein TPP1 or a small 8mer peptide (telomere dysfunction inhibitor or TELODIN) to prevent telomere uncapping, indicating an early effective intervention strategy on the mechanisms of telomere dysfunction and subsequent cellular senescence prior to differentiation disorder of pulmonary fibrosis $[35,213]$. These findings dovetail with a large body of literature indicating that telomere DDR underpins IPF [35,58,93,95,103-106,214], providing an important strategy for intervention of cell replicative senescence-associated diseases.

TPP1 is a subunit of shelterin that is a multi-subunit protein complex capping telomeric DNA $[143,144]$. We showed that pulmonary fibrosis initiated by chronic stress in mouse models is mediated by the tumor suppressor protein FBW7-mediated degradation of TPP1 [35]. FBW7 E3 ubiquitin ligase binds TPP1 and mediates stress-stimulated TPP1 multisite polyubiquitination at K299, K453 and K459, causing TPP1 degradation in proteasomes and telomere uncapping [35]. The multisite polyubiquitination of TPP1 requires FBW7 interaction with a Cdc4 phosphodegron (CPD) site $[215,216]$ in the serine/threonine $(\mathrm{S} / \mathrm{T})$ region (aa 341-482) of TPP1, with the CPD being phosphorylated by GSK3 $\beta$ at the S354 and S358 residues [35]. We showed that the binding to the phosphorylated CPD of TPP1 by FBW7 is mediated by the seventh $\beta$-strand blade containing the ${ }^{689} \mathrm{R}$ residue 
frequently mutated in cancers at the WD40 propeller domain of the C-terminal region of FBW7 [35]. Consistent with stress-mediated TPP1 degradation, thereby telomere shortening and pulmonary fibrosis, we found that under-expression of TPP1 is sufficient to induce pulmonary senescence and fibrosis, indicating that TPP1 polyubiquitination at multiple sites triggered by stress incurs telomere uncapping, DDR and shortening, resulting in pulmonary senescence and fibrosis [35]. Moreover, overexpression of TPP1 enhances respiratory physiological function with increased AEC2 stem cell population with lengthened telomeres, and confers pulmonary resistance to stress-induced onset of pulmonary fibrosis [35].

\section{Targeted Intervention of Cellular Senescence and Tissue Fibrosis}

Since cellular replicative senescence plays a causal role in tissue remodelling, it appears particularly appealing to determine if elimination or prevention of cellular replicative senescence may provide beneficial outcomes to mitigate pathogenic tissue remodelling and ageing-related disorders under various disease conditions. Considerable evidence suggests that targeted removal or prevention of cell replicative senescence alleviates SADD in fibrosis, including VIS or stress-induced fibrosis [3,35].

\subsection{Targeting Anti-Apoptotic Gene Bcl-2 to Clear Senescent Cells}

Since replicative senescence cells have upregulated anti-apoptotic proteins Bcl-w and $\mathrm{Bcl}$ XL which underpin senescent cells' antiapoptotic ability with long-term survival, drugs that inhibit Bcl survival proteins have been studied and named as senolytics for removing replicative senescence cells $[217,218]$ (Table 1). Although the U.S. Food and Drug Administration (FDA) approved the selective Bcl-2 inhibitor venetoclax (abt-199) used in leukemia, it has not had a significant effect on anti-ageing tests in vitro. Compound screening-identified that its homologue navitoclax (abt-263) effectively inhibits the effects of $\mathrm{Bcl}-2, \mathrm{Bcl}$ XL and Bcl-w, and induces apoptosis and thus clearance of replicative senescence cells [217]. In addition to abt-263, siRNAs and chemical inhibitor abt-737 simultaneously inhibit Bcl-w and Bcl XL, induce replicative senescence cell specific apoptosis, reduce RC in the populations of hematopoietic stem cells, muscle stem cells, and pulmonary and epidermal tissues of mice, with cleared replicative senescence cells harboring DNA damage and p14ARF-activated TP53 [218]. Moreover, a combination of dasatinib and quercetin (D + Q) reduces senescent cells, improving mouse idiopathic pulmonary fibrosis [219], and nerve regeneration and obesity-related anxiety behavior [220].

Recently, the use of navitoclax and D+Q selectively eliminated VIS cells and mitigated COVID-19-reminiscent lung disease with reduced inflammation in SARS-CoV-2-driven hamster and mouse models [3]. Treatment with navitoclax for less than a week to the SARS-CoV-2 infected Syrian golden hamster model with increased p16 ${ }^{\mathrm{INK} 4 \mathrm{~A}}$ led to a profound decrease in senescent cells and SALI [3]. On another hamster model of the Roborovski dwarf animals, the navitoclax or $\mathrm{D}+\mathrm{Q}$ regimen led to a substantial reduction of the cell senescence markers $\mathrm{H} 3 \mathrm{~K} 9 \mathrm{me} 3$ and $\mathrm{p} 16^{\mathrm{INK} 4 \mathrm{~A}}$ in the respiratory epithelium and increased lifespan [3]. Furthermore, in two randomized clinical trials (NCT04578158 and NCT04861298), quercetin showed significant effects of symptom improvements with significant risk reductions regarding the needs of hospitalization and oxygen therapy in a total of 194 COVID-19 patients [3]. The senolytic targeting of VIS as a novel regimen option against COVID-19 indicates that cellular replicative senescence is causative to severe stress-induced acute SADD, tissue fibrogenic remodelling, and phenotypic onset, and that eliminating cellular replicative senescence is beneficial in managing pulmonary fibrosis.

\subsection{Targeting TP53 and p16 ${ }^{I N K 4 A}$ Tumor Suppressor Genes to Clear Senescent Cells}

Recent studies have consistently shown that senescent cells can be eliminated by targeting the cells with high levels of $\mathrm{p} 16^{\mathrm{INK} 4 \mathrm{~A}}$ and TP53 tumor suppressor gene expressions. Because $\mathrm{p} 16^{\mathrm{INK} 4 \mathrm{a}}$ is significantly increased in senescent cells, AP20187 that targets FK506 using a minimal p16 ${ }^{\text {INK4a }}$ promoter element triggers a dimer formation of FK506 
binding protein and caspase- 8 to effectively induce senescent cell apoptosis, resulting in a significant reduction of the incidence and mortality of cardiovascular diseases in aged mice [221]. This regimen of $\mathrm{p} 16^{\mathrm{INK} 4 \mathrm{a}}$ sensitive caspase-8-mediated apoptosis also delays osteoporosis and persistent intervertebral disc proteoglycans [217], restores nerve regeneration in obese induced by high-fat feeding or leptin receptor deficiency, and reduces anxiety-related behaviors in mice [220]. In another model of $\mathrm{p} 16^{\mathrm{INK} 4 \mathrm{~A}}-3 \mathrm{MR}$ transgenic mice, the expression of a reporter protein (3MR) under the control of $\mathrm{p} 16^{\mathrm{INK} 4 \mathrm{~A}}$ to selectively remove senescent cells through using the small molecule compound UBX0101 reduced post-traumatic osteoarthritis and extended lifespan [222]. Furthermore, studies show that TP53 is crucial in AEC2 stem cell senescence preceding pulmonary fibrosis, especially with potential accumulation of phosphorylated TP53 at the S15 residue [38,77,223]. Therefore, the use of a FOXO4 polypeptide-harboring 60 amino acids to interfere with the interaction between FOXO4 and TP53-may be fundamental in triggering TP53-dependent apoptosis of senescent cells, delaying fibrogenesis and accelerating the rehabilitation of pulmonary ageing [223].

Table 1. Senescence-Targeting Senolytics and Other Compounds.

\begin{tabular}{|c|c|c|c|}
\hline Class & Senolytic Agent & Mechanism of Action & Reference \\
\hline $\begin{array}{l}\text { BCL-2 Family } \\
\text { Inhibitors }\end{array}$ & $\begin{array}{c}\text { Dasatinib + Quercetin } \\
\text { ABT-737 } \\
\text { ABT-263 } \\
\text { A-1331852 } \\
\text { A-1155463 }\end{array}$ & $\begin{array}{l}\text { PI3K/Akt inhibition/DNA intercalation } \\
\text { Inhibiting BCL-2, BCL-XL, BCL-W } \\
\text { Inhibiting BCL-2, BCL-XL, BCL-W } \\
\text { Inhibiting BCL-XL } \\
\text { Inhibiting BCL-XL }\end{array}$ & {$[3,217,218,220,224]$} \\
\hline Targeting p53 & $\begin{array}{c}\text { FOXO4-DRI } \\
\text { UBX0101 } \\
\text { RG7112 (RO5045337) } \\
\text { P5091 } \\
\text { P22077 } \\
\text { NOX1 and NOX2 dual inhibitor } \\
\text { PAI-1 inhibitor (TM5275) }\end{array}$ & $\begin{array}{c}\text { Disrupting FOXO4-p53 interaction } \\
\text { Disrupting MDM2-p53 interaction } \\
\text { Disrupting MDM2-p53 interaction } \\
\text { USP7 inhibitor } \\
\text { USP7 inhibitor } \\
\text { Activating p53 and apoptosis } \\
\text { Activating p53 and apoptosis }\end{array}$ & {$[222,223,225,226]$} \\
\hline HSP90 Inhibitors & $\begin{array}{l}\text { 17-DMAG (alvespimycin) } \\
\text { Geldanamycin } \\
\text { 17-AAG (tanespimycin) } \\
\text { Ganetespib }\end{array}$ & $\begin{array}{c}\text { Disrupting HSP90-AKT interaction } \\
\text { Attenuating HSP90 } \\
\text { Attenuating HSP90 } \\
\text { Attenuating HSP90 }\end{array}$ & {$[227,228]$} \\
\hline $\begin{array}{l}\text { Natural Products and } \\
\text { their Analogues }\end{array}$ & $\begin{array}{c}\text { Fisetin } \\
\text { Curcumin } \\
\text { O-Vanillin (curcumin metabolite) } \\
\text { EF-24 (curcumin analogue) } \\
\text { Piperlongumine and its analogues } \\
\text { (compounds 47-49) } \\
\text { GL-V9 }\end{array}$ & 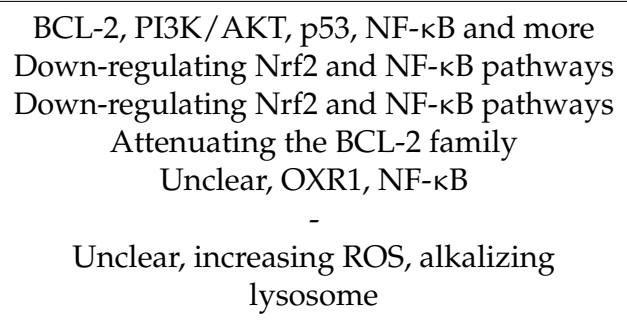 & {$[224,229-232]$} \\
\hline Cardiac Glycosides & $\begin{array}{l}\text { Proscillaridin A } \\
\text { Ouabain } \\
\text { Ouabagenin } \\
\text { Digoxin } \\
\text { Bufalin } \\
\text { K-Stropanthin } \\
\text { Strophanthidin }\end{array}$ & $\begin{array}{c}\text { Inhibiting } \mathrm{Na}^{+} / \mathrm{K}^{+} \text {-ATPase } \\
\text { Inhibiting } \mathrm{Na}^{+} / \mathrm{K}^{+} \text {-ATPase, increasing } \\
\text { BCL2-Family protein NOXA } \\
\text { Inhibiting } \mathrm{Na}^{+} / \mathrm{K}^{+} \text {-ATPase } \\
\text { Inhibiting } \mathrm{Na}^{+} / \mathrm{K}^{+} \text {-ATPase, increasing } \\
\text { BCL2-Family protein NOXA } \\
\text { Inhibiting } \mathrm{Na}^{+} / \mathrm{K}^{+} \text {-ATPase } \\
\text { Inhibiting } \mathrm{Na}^{+} / \mathrm{K}^{+} \text {-ATPase } \\
\text { Inhibiting } \mathrm{Na}^{+} / \mathrm{K}^{+} \text {-ATPase }\end{array}$ & {$[233,234]$} \\
\hline $\begin{array}{l}\text { Galactose Modified } \\
\text { Prodrugs }\end{array}$ & $\begin{array}{c}\text { SSK1 } \\
\text { Pro-drug A (JHB75B) } \\
\text { Nav-Gal } \\
\text { 5FURGa }\end{array}$ & $\begin{array}{l}\text { Targeting SA- } \beta \text {-galactosidase } \\
\text { Targeting SA- } \beta \text {-galactosidase } \\
\text { Targeting SA- } \beta \text {-galactosidase } \\
\text { Targeting SA- } \beta \text {-galactosidase }\end{array}$ & [235-237] \\
\hline
\end{tabular}


Table 1. Cont.

\begin{tabular}{|c|c|c|c|}
\hline Class & Senolytic Agent & Mechanism of Action & Reference \\
\hline PROTACs & $\begin{array}{l}\text { PZ15227 } \\
\text { ARV825 }\end{array}$ & $\begin{array}{l}\text { Degrading BCL-XL } \\
\text { Degrading BRD4 }\end{array}$ & {$[238,239]$} \\
\hline Miscellaneous & $\begin{array}{l}\text { Fenofibrate } \\
\text { Azithromycin } \\
\text { Roxithromycin } \\
\text { Tamatinib (R406) } \\
\text { MitoTam } \\
\text { Panobinostat } \\
\text { AT-406 } \\
\text { Rapamycin } \\
\text { Metformin }\end{array}$ & $\begin{array}{c}\text { PPAR } \alpha \text { agonist } \\
\text { Inducing autophagy and glycolysis } \\
\text { NOX4 } \\
\text { Syk inhibitor, FAK and p38MAPK } \\
\text { Reducing mitochondrial membrane } \\
\text { potential, Inhibiting OXPHOS } \\
\text { Histone deacetylase inhibitor } \\
\text { Inhibitor of c-IAP1, c-IAP2 and XIAP } \\
\text { Inhibiting mTOR, p16 and p21 } \\
\text { Inhibiting NF-kB pathways/AKT }\end{array}$ & [240-247] \\
\hline
\end{tabular}

\subsection{Preventing Telomere Dysfunction and Pulmonary Fibrosis by TELODIN}

By screening a peptide library, we discovered an 8-mer peptide (TELODIN) that significantly inhibited telomere dysfunction [213]. Corresponding to the $\beta$-turn hairpin-like blade 7 of FBW7 E3 ubiquitin ligase WD40 domain, as synthesized in a native or retroinverso (reversed, inversed in dextral amino acids) configuration, TELODIN competitively inhibited stress-induced TPP1 accelerated turnover, telomere shortening and pulmonary fibrosis once applied through intratracheal instillation in mice $[35,213]$. TELODIN inhalation through the respiratory airway promoted alveolar stem cell proliferation and enhanced pulmonary resistance to stress-induced pulmonary fibrogenic onset induced by different chronic stresses including ionizing radiation, or by overexpression of FBW7 in causing TPP1 deficiency, telomere uncapping and DDR [35]. The effect of TELODIN on alveolar stem cell proliferation is due to increased TPP1 and subsequently protection of telomeres against GSK3 $\beta$-primed FBW7-mediated TPP1 degradation [35,213]. Thus, to the emerged molecular target of TPP1 accelerated turnover, TELODIN prevents chronic stress induced premature pulmonary ageing and fibrosis, highlighting an effective protection of TPP1 and thus telomere dysfunction as a novel approach for intervention into pulmonary fibrosis.

\section{Conclusions and Perspectives}

Pulmonary ageing and fibrosis occur in association with AEC2 stem cell senescence and SADD. AEC2 stem cell failure of differentiation to AEC1 cells in epithelial damage repair, and trans-differentiation to mesenchymal fibrogenic remodeling, are the two critical cellular processes mediated by telomere dysfunction. Downstream of stress-induced uncapping of telomeres or TGF- $\beta$-signaling repression of the telomerase TERT gene, AEC2 stem cell senescence drives alveolar epithelial fibrogenesis, representing a key molecular target for intervention. Preventing AEC2 stem cell senescence by promoting telomere capping integrity using TELODIN, or removing senescent cells by promoting apoptosis using senolytics, is emerging as a promising strategy in the studies of pulmonary fibrosis intervention.

More investigations are underway to detect and intervene in stress-induced premature pulmonary senescence and the early stage of fibrosis, informing molecular targeting strategies of prophylactic and therapeutic intervention. The contemporary strategies and technologies-such as sequencing single cell populations to differentiate gene profiling of cell senescence and differentiation statues, deciphering structural modifications post gene transcription, defining disordered molecular networks, and decoding denatured macromolecules and compromised protective complexes-will lead to more studies of interventions of alveolar stem cell senescence and SADD in pulmonary fibrogenesis. Dissecting cellular and molecular interplays will likely produce further insights into the development of premature cellular senescence and fibrosis for some prophylactic and therapeutic outcomes. 


\begin{abstract}
Author Contributions: X.H. conceived and wrote the manuscript. L.W., K.Z. and J.L. participated in writing. J.-P.L. conceived, supervised and wrote the manuscript. All authors contributed to the discussions and presentations. All authors have read and agreed to the published version of the manuscript.
\end{abstract}

Funding: This research was funded by National Key Research and Development Program of China (2018YFC2000100, and 2021ZD0202402), the National Natural Science Foundation of China (91949207, 82130044, 92149302, 91849124, and 81871112), and the Victorian Government's Operational Infrastructure Support Program of Australia.

Acknowledgments: This work was supported by grants from the National Key Research and Development Program of China (2018YFC2000100, and 2021ZD0202402), the National Natural Science Foundation of China (91949207, 82130044, 92149302, 91849124, and 81871112), and the Victorian Government's Operational Infrastructure Support Program of Australia.

Conflicts of Interest: The authors declare no conflict of interest.

\title{
References
}

1. Cookson, W.O.; Moffatt, M.F. Bedside to gene and back in idiopathic pulmonary fibrosis. N. Engl. J. Med. 2013, 368, 2228-2230. [CrossRef] [PubMed]

2. Armanios, M.Y. Telomerase mutations in families with idiopathic pulmonary fibrosis. N. Engl. J. Med. 2007, 356, 1370-1372. [CrossRef] [PubMed]

3. Lee, S.; Yu, Y.; Trimpert, J.; Benthani, F.; Mairhofer, M.; Richter-Pechanska, P.; Wyler, E.; Belenki, D.; Kaltenbrunner, S.; Pammer, M.; et al. Virus-induced senescence is driver and therapeutic target in COVID-19. Nature 2021, 599, 283-289. [CrossRef] [PubMed]

4. Wang, S.; Yao, X.; Ma, S.; Ping, Y.; Fan, Y.; Sun, S.; He, Z.; Shi, Y.; Sun, L.; Xiao, S.; et al. A single-cell transcriptomic landscape of the lungs of patients with COVID-19. Nat. Cell Biol. 2021, 23, 1314-1328. [CrossRef]

5. Nie, X.; Qian, L.; Sun, R.; Huang, B.; Dong, X.; Xiao, Q.; Zhang, Q.; Lu, T.; Yue, L.; Chen, S.; et al. Multi-organ proteomic landscape of COVID-19 autopsies. Cell 2021, 184, 775-791.e14. [CrossRef]

6. Armanios, M.Y.; Chen, J.J.; Cogan, J.D.; Alder, J.K.; Ingersoll, R.G.; Markin, C.; Lawson, W.E.; Xie, M.; Vulto, I.; Phillips, J.A., 3rd; et al. Telomerase mutations in families with idiopathic pulmonary fibrosis. N. Engl. J. Med. 2007, 356, 1317-1326. [CrossRef]

7. Ting, C.; Aspal, M.; Vaishampayan, N.; Huang, S.K.; Wang, F.; Farver, C.; Zemans, R.L. Ineffectual AEC1 differentiation from KRT8 (hi) transitional state without fibrosis is associated with fatal COVID-19 ARDS. bioRxiv 2021. [CrossRef]

8. Drake, T.M.; Docherty, A.B.; Harrison, E.M.; Quint, J.K.; Adamali, H.; Agnew, S.; Babu, S.; Barber, C.M.; Barratt, S.; Bendstrup, E.; et al. Outcome of Hospitalization for COVID-19 in Patients with Interstitial Lung Disease. An International Multicenter Study. Am. J. Respir. Crit. Care Med. 2020, 202, 1656-1665. [CrossRef]

9. Jansing, N.L.; McClendon, J.; Henson, P.M.; Tuder, R.M.; Hyde, D.M.; Zemans, R.L. Unbiased Quantitation of Alveolar Type II to Alveolar Type I Cell Transdifferentiation during Repair after Lung Injury in Mice. Am. J. Respir. Cell Mol. Biol. 2017, 57, 519-526. [CrossRef]

10. Barkauskas, C.E.; Cronce, M.J.; Rackley, C.R.; Bowie, E.J.; Keene, D.R.; Stripp, B.R.; Randell, S.H.; Noble, P.W.; Hogan, B.L. Type 2 alveolar cells are stem cells in adult lung. J. Clin. Investig. 2013, 123, 3025-3036. [CrossRef]

11. Kathiriya, J.J.; Brumwell, A.N.; Jackson, J.R.; Tang, X.; Chapman, H.A. Distinct Airway Epithelial Stem Cells Hide among Club Cells but Mobilize to Promote Alveolar Regeneration. Cell Stem Cell 2020, 26, 346-358.e4. [CrossRef] [PubMed]

12. Rao, W.; Wang, S.; Duleba, M.; Niroula, S.; Goller, K.; Xie, J.; Mahalingam, R.; Neupane, R.; Liew, A.A.; Vincent, M.; et al. Regenerative Metaplastic Clones in COPD Lung Drive Inflammation and Fibrosis. Cell 2020, 181, 848-864.e18. [CrossRef]

13. Lee, J.H.; Bhang, D.H.; Beede, A.; Huang, T.L.; Stripp, B.R.; Bloch, K.D.; Wagers, A.J.; Tseng, Y.H.; Ryeom, S.; Kim, C.F. Lung stem cell differentiation in mice directed by endothelial cells via a BMP4-NFATc1-thrombospondin-1 axis. Cell 2014, 156, 440-455. [CrossRef]

14. Chen, Q.; Suresh Kumar, V.; Finn, J.; Jiang, D.; Liang, J.; Zhao, Y.Y.; Liu, Y. CD44(high) alveolar type II cells show stem cell properties during steady-state alveolar homeostasis. Am. J. Physiol. Lung Cell. Mol. Physiol. 2017, 313, L41-L51. [CrossRef] [PubMed]

15. Reddy, R.; Buckley, S.; Doerken, M.; Barsky, L.; Weinberg, K.; Anderson, K.D.; Warburton, D.; Driscoll, B. Isolation of a putative progenitor subpopulation of alveolar epithelial type 2 cells. Am. J. Physiol. Lung Cell. Mol. Physiol. 2004, 286, 658-667. [CrossRef] [PubMed]

16. Salahudeen, A.A.; Choi, S.S.; Rustagi, A.; Zhu, J.; van Unen, V.; de la O, S.M.; Flynn, R.A.; Margalef-Catala, M.; Santos, A.J.M.; Ju, J.; et al. Progenitor identification and SARS-CoV-2 infection in human distal lung organoids. Nature 2020, 588, 670-675. [CrossRef] [PubMed]

17. Nabhan, A.N.; Brownfield, D.G.; Harbury, P.B.; Krasnow, M.A.; Desai, T.J. Single-cell Wnt signaling niches maintain stemness of alveolar type 2 cells. Science 2018, 359, 1118-1123. [CrossRef]

18. Choi, J.; Park, J.E.; Tsagkogeorga, G.; Yanagita, M.; Koo, B.K.; Han, N.; Lee, J.H. Inflammatory Signals Induce AT2 Cell-Derived Damage-Associated Transient Progenitors that Mediate Alveolar Regeneration. Cell Stem Cell 2020, 27, 366-382.e7. [CrossRef] 
19. Kobayashi, Y.; Tata, A.; Konkimalla, A.; Katsura, H.; Lee, R.F.; Ou, J.; Banovich, N.E.; Kropski, J.A.; Tata, P.R. Persistence of a regeneration-associated, transitional alveolar epithelial cell state in pulmonary fibrosis. Nat. Cell Biol. 2020, 22, 934-946. [CrossRef]

20. Strunz, M.; Simon, L.M.; Ansari, M.; Kathiriya, J.J.; Angelidis, I.; Mayr, C.H.; Tsidiridis, G.; Lange, M.; Mattner, L.F.; Yee, M.; et al. Alveolar regeneration through a Krt8+ transitional stem cell state that persists in human lung fibrosis. Nat. Commun. 2020, 11, 3559. [CrossRef]

21. Jiang, P.; Gil de Rubio, R.; Hrycaj, S.M.; Gurczynski, S.J.; Riemondy, K.A.; Moore, B.B.; Omary, M.B.; Ridge, K.M.; Zemans, R.L. Ineffectual Type 2-to-Type 1 Alveolar Epithelial Cell Differentiation in Idiopathic Pulmonary Fibrosis: Persistence of the KRT8(hi) Transitional State. Am. J. Respir. Crit. Care Med. 2020, 201, 1443-1447. [CrossRef] [PubMed]

22. Riemondy, K.A.; Jansing, N.L.; Jiang, P.; Redente, E.F.; Gillen, A.E.; Fu, R.; Miller, A.J.; Spence, J.R.; Gerber, A.N.; Hesselberth, J.R.; et al. Single cell RNA sequencing identifies TGFbeta as a key regenerative cue following LPS-induced lung injury. JCI Insight 2019, 4, e123637. [CrossRef] [PubMed]

23. Wu, H.; Yu, Y.; Huang, H.; Hu, Y.; Fu, S.; Wang, Z.; Shi, M.; Zhao, X.; Yuan, J.; Li, J.; et al. Progressive Pulmonary Fibrosis Is Caused by Elevated Mechanical Tension on Alveolar Stem Cells. Cell 2020, 180, 107-121.e4. [CrossRef] [PubMed]

24. Salama, R.; Sadaie, M.; Hoare, M.; Narita, M. Cellular senescence and its effector programs. Genes Dev. 2014, 28, 99-114. [CrossRef]

25. Hayflick, L.; Moorhead, P.S. The serial cultivation of human diploid cell strains. Exp. Cell Res. 1961, 25, 585-621. [CrossRef]

26. Munoz-Espin, D.; Serrano, M. Cellular senescence: From physiology to pathology. Nat. Rev. Mol. Cell Biol 2014, 15, 482-496. [CrossRef]

27. Maciel-Baron, L.A.; Morales-Rosales, S.L.; Aquino-Cruz, A.A.; Triana-Martinez, F.; Galvan-Arzate, S.; Luna-Lopez, A.; GonzalezPuertos, V.Y.; Lopez-Diazguerrero, N.E.; Torres, C.; Konigsberg, M. Senescence associated secretory phenotype profile from primary lung mice fibroblasts depends on the senescence induction stimuli. Age 2016, 38, 26. [CrossRef]

28. Balaban, R.S.; Nemoto, S.; Finkel, T. Mitochondria, oxidants, and aging. Cell 2005, 120, 483-495. [CrossRef]

29. Rivera, T.; Haggblom, C.; Cosconati, S.; Karlseder, J. A balance between elongation and trimming regulates telomere stability in stem cells. Nat. Struct. Mol. Biol. 2017, 24, 30-39. [CrossRef]

30. Paluvai, H.; Di Giorgio, E.; Brancolini, C. The Histone Code of Senescence. Cells 2020, 9, 466. [CrossRef]

31. Sati, S.; Bonev, B.; Szabo, Q.; Jost, D.; Bensadoun, P.; Serra, F.; Loubiere, V.; Papadopoulos, G.L.; Rivera-Mulia, J.C.; Fritsch, L.; et al. 4D Genome Rewiring during Oncogene-Induced and Replicative Senescence. Mol. Cell 2020, 78, 522-538.e9. [CrossRef] [PubMed]

32. Campaner, S.; Doni, M.; Hydbring, P.; Verrecchia, A.; Bianchi, L.; Sardella, D.; Schleker, T.; Perna, D.; Tronnersjo, S.; Murga, M.; et al. Cdk2 suppresses cellular senescence induced by the c-myc oncogene. Nat. Cell Biol. 2010, 12, 54-59. [CrossRef] [PubMed]

33. Laberge, R.M.; Sun, Y.; Orjalo, A.V.; Patil, C.K.; Freund, A.; Zhou, L.; Curran, S.C.; Davalos, A.R.; Wilson-Edell, K.A.; Liu, S.; et al. MTOR regulates the pro-tumorigenic senescence-associated secretory phenotype by promoting IL1A translation. Nat. Cell Biol. 2015, 17, 1049-1061. [CrossRef]

34. Sieben, C.J.; Sturmlechner, I.; van de Sluis, B.; van Deursen, J.M. Two-Step Senescence-Focused Cancer Therapies. Trends Cell Biol. 2018, 28, 723-737. [CrossRef]

35. Wang, L.; Chen, R.; Li, G.; Wang, Z.; Liu, J.; Liang, Y.; Liu, J.P. FBW7 Mediates Senescence and Pulmonary Fibrosis through Telomere Uncapping. Cell Metab. 2020, 32, 860-877.e9. [CrossRef] [PubMed]

36. Sharpless, N.E.; Sherr, C.J. Forging a signature of In Vivo senescence. Nat. Rev. Cancer 2015, 15, 397-408. [CrossRef] [PubMed]

37. Ito, Y.; Hoare, M.; Narita, M. Spatial and Temporal Control of Senescence. Trends Cell Biol. 2017, 27, 820-832. [CrossRef] [PubMed]

38. Yao, C.; Guan, X.; Carraro, G.; Parimon, T.; Liu, X.; Huang, G.; Mulay, A.; Soukiasian, H.J.; David, G.; Weigt, S.S.; et al. Senescence of Alveolar Type 2 Cells Drives Progressive Pulmonary Fibrosis. Am. J. Respir. Crit. Care Med. 2021, 203, 707-717. [CrossRef]

39. Zhang, K.; Chen, C.; Liu, Y.; Chen, H.; Liu, J.P. Cellular senescence occurred widespread to multiple selective sites in the fetal tissues and organs of mice. Clin. Exp. Pharmacol. Physiol. 2014, 41, 965-975. [CrossRef]

40. Dorr, J.R.; Yu, Y.; Milanovic, M.; Beuster, G.; Zasada, C.; Dabritz, J.H.; Lisec, J.; Lenze, D.; Gerhardt, A.; Schleicher, K.; et al. Synthetic lethal metabolic targeting of cellular senescence in cancer therapy. Nature 2013, 501, 421-425. [CrossRef]

41. Milanovic, M.; Fan, D.N.Y.; Belenki, D.; Däbritz, J.H.M.; Zhao, Z.; Yu, Y.; Dörr, J.R.; Dimitrova, L.; Lenze, D.; Monteiro Barbosa, I.A.; et al. Senescence-associated reprogramming promotes cancer stemness. Nature 2018, 553, 96-100. [CrossRef] [PubMed]

42. Patel, P.L.; Suram, A.; Mirani, N.; Bischof, O.; Herbig, U. Derepression of hTERT gene expression promotes escape from oncogene-induced cellular senescence. Proc. Natl. Acad. Sci. USA 2016, 113, 5024-5033. [CrossRef] [PubMed]

43. Reyes, J.; Chen, J.Y.; Stewart-Ornstein, J.; Karhohs, K.W.; Mock, C.S.; Lahav, G. Fluctuations in p53 Signaling Allow Escape from Cell-Cycle Arrest. Mol. Cell 2018, 71, 581-591.e5. [CrossRef] [PubMed]

44. Baryshev, M.; Inashkina, I.; Salmina, K.; Huna, A.; Jackson, T.R.; Erenpreisa, J. DNA methylation of the Oct4A enhancers in embryonal carcinoma cells after etoposide treatment is associated with alternative splicing and altered pluripotency in reversibly senescent cells. Cell Cycle 2018, 17, 362-366. [CrossRef]

45. Mosteiro, L.; Pantoja, C.; Alcazar, N.; Marión, R.M.; Chondronasiou, D.; Rovira, M.; Fernandez-Marcos, P.J.; Muñoz-Martin, M.; Blanco-Aparicio, C.; Pastor, J.; et al. Tissue damage and senescence provide critical signals for cellular reprogramming In Vivo. Science 2016, 354, aaf4445. [CrossRef]

46. Ritschka, B.; Storer, M.; Mas, A.; Heinzmann, F.; Ortells, M.C.; Morton, J.P.; Sansom, O.J.; Zender, L.; Keyes, W.M. The senescenceassociated secretory phenotype induces cellular plasticity and tissue regeneration. Genes Dev. 2017, 31, 172-183. [CrossRef] 
47. Demaria, M.; O'Leary, M.N.; Chang, J.; Shao, L.; Liu, S.; Alimirah, F.; Koenig, K.; Le, C.; Mitin, N.; Deal, A.M.; et al. Cellular Senescence Promotes Adverse Effects of Chemotherapy and Cancer Relapse. Cancer Discov. 2017, 7, 165-176. [CrossRef]

48. Campisi, J. Senescent cells, tumor suppression, and organismal aging: Good citizens, bad neighbors. Cell 2005, 120, 513-522 [CrossRef]

49. Coppe, J.P.; Desprez, P.Y.; Krtolica, A.; Campisi, J. The senescence-associated secretory phenotype: The dark side of tumor suppression. Annu. Rev. Pathol. 2010, 5, 99-118. [CrossRef]

50. Hernandez-Segura, A.; de Jong, T.V.; Melov, S.; Guryev, V.; Campisi, J.; Demaria, M. Unmasking Transcriptional Heterogeneity in Senescent Cells. Curr. Biol. CB 2017, 27, 2652-2660.e4. [CrossRef]

51. Takasugi, M.; Okada, R.; Takahashi, A.; Virya Chen, D.; Watanabe, S.; Hara, E. Small extracellular vesicles secreted from senescent cells promote cancer cell proliferation through EphA2. Nat. Commun. 2017, 8, 15729. [CrossRef] [PubMed]

52. Takahashi, A.; Okada, R.; Nagao, K.; Kawamata, Y.; Hanyu, A.; Yoshimoto, S.; Takasugi, M.; Watanabe, S.; Kanemaki, M.T.; Obuse, C.; et al. Exosomes maintain cellular homeostasis by excreting harmful DNA from cells. Nat. Commun. 2017, 8, 15287. [CrossRef] [PubMed]

53. Lehmann, B.D.; Paine, M.S.; Brooks, A.M.; McCubrey, J.A.; Renegar, R.H.; Wang, R.; Terrian, D.M. Senescence-associated exosome release from human prostate cancer cells. Cancer Res. 2008, 68, 7864-7871. [CrossRef] [PubMed]

54. Konopka, K.E.; Nguyen, T.; Jentzen, J.M.; Rayes, O.; Schmidt, C.J.; Wilson, A.M.; Farver, C.F.; Myers, J.L. Diffuse alveolar damage (DAD) resulting from coronavirus disease 2019 Infection is Morphologically Indistinguishable from Other Causes of DAD. Histopathology 2020, 77, 570-578. [CrossRef]

55. Carsana, L.; Sonzogni, A.; Nasr, A.; Rossi, R.S.; Pellegrinelli, A.; Zerbi, P.; Rech, R.; Colombo, R.; Antinori, S.; Corbellino, M.; et al Pulmonary post-mortem findings in a series of COVID-19 cases from northern Italy: A two-centre descriptive study. Lancet Infect. Dis. 2020, 20, 1135-1140. [CrossRef]

56. Adams, T.S.; Schupp, J.C.; Poli, S.; Ayaub, E.A.; Neumark, N.; Ahangari, F.; Chu, S.G.; Raby, B.A.; DeIuliis, G.; Januszyk, M.; et al. Single-cell RNA-seq reveals ectopic and aberrant lung-resident cell populations in idiopathic pulmonary fibrosis. Sci. Adv. 2020, 6, eaba1983. [CrossRef] [PubMed]

57. Habermann, A.C.; Gutierrez, A.J.; Bui, L.T.; Yahn, S.L.; Winters, N.I.; Calvi, C.L.; Peter, L.; Chung, M.I.; Taylor, C.J.; Jetter, C.; et al. Single-cell RNA sequencing reveals profibrotic roles of distinct epithelial and mesenchymal lineages in pulmonary fibrosis. Sci. Adv. 2020, 6, eaba1972. [CrossRef]

58. Alder, J.K.; Barkauskas, C.E.; Limjunyawong, N.; Stanley, S.E.; Kembou, F.; Tuder, R.M.; Hogan, B.L.; Mitzner, W.; Armanios, M. Telomere dysfunction causes alveolar stem cell failure. Proc. Natl. Acad. Sci. USA 2015, 112, 5099-5104. [CrossRef]

59. Razdan, N.; Vasilopoulos, T.; Herbig, U. Telomere dysfunction promotes transdifferentiation of human fibroblasts into myofibroblasts. Aging Cell 2018, 17, e12838. [CrossRef]

60. Lee, J.; Reddy, R.; Barsky, L.; Scholes, J.; Chen, H.; Shi, W.; Driscoll, B. Lung alveolar integrity is compromised by telomere shortening in telomerase-null mice. Am. J. Physiol. Lung Cell. Mol. Physiol. 2009, 296, 57-70. [CrossRef]

61. Willis, B.C.; Liebler, J.M.; Luby-Phelps, K.; Nicholson, A.G.; Crandall, E.D.; du Bois, R.M.; Borok, Z. Induction of epithelialmesenchymal transition in alveolar epithelial cells by transforming growth factor-beta1: Potential role in idiopathic pulmonary fibrosis. Am. J. Pathol. 2005, 166, 1321-1332. [CrossRef]

62. Marmai, C.; Sutherland, R.E.; Kim, K.K.; Dolganov, G.M.; Fang, X.; Kim, S.S.; Jiang, S.; Golden, J.A.; Hoopes, C.W.; Matthay, M.A.; et al. Alveolar epithelial cells express mesenchymal proteins in patients with idiopathic pulmonary fibrosis. Am. J. Physiol. Lung Cell. Mol. Physiol. 2011, 301, 71-78. [CrossRef] [PubMed]

63. Kim, K.K.; Kugler, M.C.; Wolters, P.J.; Robillard, L.; Galvez, M.G.; Brumwell, A.N.; Sheppard, D.; Chapman, H.A. Alveolar epithelial cell mesenchymal transition develops In Vivo during pulmonary fibrosis and is regulated by the extracellular matrix. Proc. Natl. Acad. Sci. USA 2006, 103, 13180-13185. [CrossRef] [PubMed]

64. Bharat, A.; Querrey, M.; Markov, N.S.; Kim, S.; Kurihara, C.; Garza-Castillon, R.; Manerikar, A.; Shilatifard, A.; Tomic, R.; Politanska, Y.; et al. Lung transplantation for patients with severe COVID-19. Sci. Transl. Med. 2020, 12, eabe4282. [CrossRef]

65. Chen, J.; Wu, H.; Yu, Y.; Tang, N. Pulmonary alveolar regeneration in adult COVID-19 patients. Cell Res. 2020, 30, 708-710. [CrossRef]

66. Kulkarni, T.; de Andrade, J.; Zhou, Y.; Luckhardt, T.; Thannickal, V.J. Alveolar epithelial disintegrity in pulmonary fibrosis. Am. J. Physiol. Lung Cell. Mol. Physiol. 2016, 311, 185-191. [CrossRef]

67. Chung, M.I.; Bujnis, M.; Barkauskas, C.E.; Kobayashi, Y.; Hogan, B.L.M. Niche-mediated BMP/SMAD signaling regulates lung alveolar stem cell proliferation and differentiation. Development 2018, 145, dev163014. [CrossRef]

68. Schruf, E.; Schroeder, V.; Le, H.Q.; Schonberger, T.; Raedel, D.; Stewart, E.L.; Fundel-Clemens, K.; Bluhmki, T.; Weigle, S.; Schuler, M.; et al. Recapitulating idiopathic pulmonary fibrosis related alveolar epithelial dysfunction in a human iPSC-derived air-liquid interface model. FASEB J. 2020, 34, 7825-7846. [CrossRef]

69. Gokey, J.J.; Snowball, J.; Green, J.; Waltamath, M.; Spinney, J.J.; Black, K.E.; Hariri, L.P.; Xu, Y.; Perl, A.K. Pretreatment of aged mice with retinoic acid supports alveolar regeneration via upregulation of reciprocal PDGFA signalling. Thorax 2021, 76, 456-467. [CrossRef]

70. Zheng, X.; Qi, C.; Zhang, S.; Fang, Y.; Ning, W. TGF-beta1 induces Fstl1 via the Smad3-c-Jun pathway in lung fibroblasts. Am. J. Physiol. Lung Cell. Mol. Physiol. 2017, 313, 240-251. [CrossRef] 
71. Kim, K.K.; Wei, Y.; Szekeres, C.; Kugler, M.C.; Wolters, P.J.; Hill, M.L.; Frank, J.A.; Brumwell, A.N.; Wheeler, S.E.; Kreidberg, J.A.; et al. Epithelial cell alpha3beta1 integrin links beta-catenin and Smad signaling to promote myofibroblast formation and pulmonary fibrosis. J. Clin. Investig. 2009, 119, 213-224. [CrossRef] [PubMed]

72. Namba, T.; Tanaka, K.I.; Ito, Y.; Hoshino, T.; Matoyama, M.; Yamakawa, N.; Isohama, Y.; Azuma, A.; Mizushima, T. Induction of EMT-like phenotypes by an active metabolite of leflunomide and its contribution to pulmonary fibrosis. Cell Death Differ. 2010, 17, 1882-1895. [CrossRef] [PubMed]

73. Schneider, D.J.; Wu, M.; Le, T.T.; Cho, S.H.; Brenner, M.B.; Blackburn, M.R.; Agarwal, S.K. Cadherin- 11 contributes to pulmonary fibrosis: Potential role in TGF-beta production and epithelial to mesenchymal transition. FASEB J. 2012, 26, 503-512. [CrossRef] [PubMed]

74. Tanjore, H.; Cheng, D.S.; Degryse, A.L.; Zoz, D.F.; Abdolrasulnia, R.; Lawson, W.E.; Blackwell, T.S. Alveolar epithelial cells undergo epithelial-to-mesenchymal transition in response to endoplasmic reticulum stress. J. Biol. Chem. 2011, 286, 30972-30980. [CrossRef]

75. Tanjore, H.; Xu, X.C.; Polosukhin, V.V.; Degryse, A.L.; Li, B.; Han, W.; Sherrill, T.P.; Plieth, D.; Neilson, E.G.; Blackwell, T.S.; et al. Contribution of epithelial-derived fibroblasts to bleomycin-induced lung fibrosis. Am. J. Respir. Crit. Care Med. 2009, 180, 657-665. [CrossRef]

76. Zhou, B.; Liu, Y.; Kahn, M.; Ann, D.K.; Han, A.; Wang, H.; Nguyen, C.; Flodby, P.; Zhong, Q.; Krishnaveni, M.S.; et al. Interactions between $\beta$-catenin and transforming growth factor- $\beta$ signaling pathways mediate epithelial-mesenchymal transition and are dependent on the transcriptional co-activator cAMP-response element-binding protein (CREB)-binding protein (CBP). J. Biol. Chem. 2012, 287, 7026-7038. [CrossRef]

77. Zhang, K.; Wang, L.; Hong, X.; Chen, H.; Shi, Y.; Liu, Y.; Liu, J.; Liu, J.P. Pulmonary Alveolar Stem Cell Senescence, Apoptosis, and Differentiation by p53-Dependent and -Independent Mechanisms in Telomerase-Deficient Mice. Cells 2021, 10, 2892. [CrossRef]

78. Chen, R.; Zhang, K.; Chen, H.; Zhao, X.; Wang, J.; Li, L.; Cong, Y.; Ju, Z.; Xu, D.; Williams, B.R.; et al. Telomerase deficiency causes alveolar stem cell senescence-associated low-grade inflammation in lungs. J. Biol. Chem. 2015, 290, 30813-30829. [CrossRef]

79. Wang, L.; Yu, X.; Liu, J.P. Telomere Damage Response and Low-Grade Inflammation. Adv. Exp. Med. Biol 2017, 1024, 213-224. [CrossRef]

80. Birnhuber, A.; Egemnazarov, B.; Biasin, V.; Bonyadi Rad, E.; Wygrecka, M.; Olschewski, H.; Kwapiszewska, G.; Marsh, L.M. CDK4/6 inhibition enhances pulmonary inflammatory infiltration in bleomycin-induced lung fibrosis. Respir. Res. 2020, $21,167$. [CrossRef]

81. Sala, M.A.; Balderas-Martinez, Y.I.; Buendia-Roldan, I.; Abdala-Valencia, H.; Nam, K.; Jain, M.; Bhorade, S.; Bharat, A.; Reyfman, P.A.; Ridge, K.M.; et al. Inflammatory pathways are upregulated in the nasal epithelium in patients with idiopathic pulmonary fibrosis. Respir. Res. 2018, 19, 233. [CrossRef] [PubMed]

82. Li, M.; Krishnaveni, M.S.; Li, C.; Zhou, B.; Xing, Y.; Banfalvi, A.; Li, A.; Lombardi, V.; Akbari, O.; Borok, Z.; et al. Epitheliumspecific deletion of TGF-beta receptor type II protects mice from bleomycin-induced pulmonary fibrosis. J. Clin. Investig. 2011, 121, 277-287. [CrossRef] [PubMed]

83. Aumiller, V.; Balsara, N.; Wilhelm, J.; Gunther, A.; Konigshoff, M. WNT/beta-catenin signaling induces IL-1beta expression by alveolar epithelial cells in pulmonary fibrosis. Am. J. Respir. Cell Mol. Biol. 2013, 49, 96-104. [CrossRef] [PubMed]

84. Yu, G.; Tzouvelekis, A.; Wang, R.; Herazo-Maya, J.D.; Ibarra, G.H.; Srivastava, A.; de Castro, J.P.W.; DeIuliis, G.; Ahangari, F.; Woolard, T.; et al. Thyroid hormone inhibits lung fibrosis in mice by improving epithelial mitochondrial function. Nat. Med. 2018, 24, 39-49. [CrossRef]

85. Cheresh, P.; Kim, S.J.; Tulasiram, S.; Kamp, D.W. Oxidative stress and pulmonary fibrosis. Biochim. Biophys. Acta 2013, 1832, 1028-1040. [CrossRef] [PubMed]

86. Otoupalova, E.; Smith, S.; Cheng, G.; Thannickal, V.J. Oxidative Stress in Pulmonary Fibrosis. Compr. Physiol. 2020, 10, 509-547. [CrossRef]

87. Korthagen, N.M.; van Moorsel, C.H.; Barlo, N.P.; Kazemier, K.M.; Ruven, H.J.; Grutters, J.C. Association between variations in cell cycle genes and idiopathic pulmonary fibrosis. PLoS ONE 2012, 7, e30442. [CrossRef]

88. Dressen, A.; Abbas, A.R.; Cabanski, C.; Reeder, J.; Ramalingam, T.R.; Neighbors, M.; Bhangale, T.R.; Brauer, M.J.; Hunkapiller, J.; Reeder, J.; et al. Analysis of protein-altering variants in telomerase genes and their association with MUC5B common variant status in patients with idiopathic pulmonary fibrosis: A candidate gene sequencing study. Lancet Respir. Med. 2018, 6, 603-614. [CrossRef]

89. King, T.E., Jr.; Pardo, A.; Selman, M. Idiopathic pulmonary fibrosis. Lancet 2011, 378, 1949-1961. [CrossRef]

90. Tsakiri, K.D.; Cronkhite, J.T.; Kuan, P.J.; Xing, C.; Raghu, G.; Weissler, J.C.; Rosenblatt, R.L.; Shay, J.W.; Garcia, C.K. Adult-onset pulmonary fibrosis caused by mutations in telomerase. Proc. Natl. Acad. Sci. USA 2007, 104, 7552-7557. [CrossRef]

91. Stuart, B.D.; Choi, J.; Zaidi, S.; Xing, C.; Holohan, B.; Chen, R.; Choi, M.; Dharwadkar, P.; Torres, F.; Girod, C.E.; et al. Exome sequencing links mutations in PARN and RTEL1 with familial pulmonary fibrosis and telomere shortening. Nat. Genet. 2015, 47, 512-517. [CrossRef] [PubMed]

92. Sousa, S.R.; Caetano Mota, P.; Melo, N.; Bastos, H.N.; Padrao, E.; Pereira, J.M.; Cunha, R.; Souto Moura, C.; Guimaraes, S.; Morais, A. Heterozygous TERT gene mutation associated with familial idiopathic pulmonary fibrosis. Respir. Med. Case Rep. 2019, 26, 118-122. [CrossRef] [PubMed] 
93. Alder, J.K.; Chen, J.J.; Lancaster, L.; Danoff, S.; Su, S.C.; Cogan, J.D.; Vulto, I.; Xie, M.; Qi, X.; Tuder, R.M.; et al. Short telomeres are a risk factor for idiopathic pulmonary fibrosis. Proc. Natl. Acad. Sci. USA 2008, 105, 13051-13056. [CrossRef] [PubMed]

94. Alder, J.K.; Cogan, J.D.; Brown, A.F.; Anderson, C.J.; Lawson, W.E.; Lansdorp, P.M.; Phillips, J.A., 3rd; Loyd, J.E.; Chen, J.J.; Armanios, M. Ancestral mutation in telomerase causes defects in repeat addition processivity and manifests as familial pulmonary fibrosis. PLoS Genet. 2011, 7, e1001352. [CrossRef]

95. Armanios, M. Syndromes of Telomere Shortening. Annu Rev. Genom. Hum. Genet. 2009, 62, 6405-6409. [CrossRef]

96. Petrovski, S.; Todd, J.L.; Durheim, M.T.; Wang, Q.; Chien, J.W.; Kelly, F.L.; Frankel, C.; Mebane, C.M.; Ren, Z.; Bridgers, J.; et al. An Exome Sequencing Study to Assess the Role of Rare Genetic Variation in Pulmonary Fibrosis. Am. J. Respir. Crit. Care Med. 2017, 196, 82-93. [CrossRef]

97. Chilosi, M.; Poletti, V.; Rossi, A. The pathogenesis of COPD and IPF: Distinct horns of the same devil? Respir. Res. 2012, 13, 3. [CrossRef]

98. Nogee, L.M.; Dunbar, A.E., 3rd; Wert, S.E.; Askin, F.; Hamvas, A.; Whitsett, J.A. A mutation in the surfactant protein C gene associated with familial interstitial lung disease. N. Engl. J. Med. 2001, 344, 573-579. [CrossRef]

99. Cottin, V.; Reix, P.; Khouatra, C.; Thivolet-Bejui, F.; Feldmann, D.; Cordier, J.F. Combined pulmonary fibrosis and emphysema syndrome associated with familial SFTPC mutation. Thorax 2011, 66, 918-919. [CrossRef]

100. Nathan, N.; Giraud, V.; Picard, C.; Nunes, H.; Dastot-Le Moal, F.; Copin, B.; Galeron, L.; De Ligniville, A.; Kuziner, N.; ReynaudGaubert, M.; et al. Germline SFTPA1 mutation in familial idiopathic interstitial pneumonia and lung cancer. Hum. Mol. Genet. 2016, 25, 1457-1467. [CrossRef]

101. Wu, J.; McKeague, M.; Sturla, S.J. Nucleotide-Resolution Genome-Wide Mapping of Oxidative DNA Damage by Click-Code-Seq. J. Am. Chem Soc. 2018, 140, 9783-9787. [CrossRef] [PubMed]

102. Qian, W.; Kumar, N.; Roginskaya, V.; Fouquerel, E.; Opresko, P.L.; Shiva, S.; Watkins, S.C.; Kolodieznyi, D.; Bruchez, M.P.; Van Houten, B. Chemoptogenetic damage to mitochondria causes rapid telomere dysfunction. Proc. Natl. Acad. Sci. USA 2019, 116, 18435-18444. [CrossRef] [PubMed]

103. Hewitt, G.; Jurk, D.; Marques, F.D.; Correia-Melo, C.; Hardy, T.; Gackowska, A.; Anderson, R.; Taschuk, M.; Mann, J.; Passos, J.F Telomeres are favoured targets of a persistent DNA damage response in ageing and stress-induced senescence. Nat. Commun. 2012, 3, 708. [CrossRef] [PubMed]

104. Degryse, A.L.; Xu, X.C.; Newman, J.L.; Mitchell, D.B.; Tanjore, H.; Polosukhin, V.V.; Jones, B.R.; McMahon, F.B.; Gleaves, L.A.; Phillips, J.A., 3rd; et al. Telomerase deficiency does not alter bleomycin-induced fibrosis in mice. Exp. Lung Res. 2012, 38, 124-134. [CrossRef] [PubMed]

105. Fumagalli, M.; Rossiello, F.; Clerici, M.; Barozzi, S.; Cittaro, D.; Kaplunov, J.M.; Bucci, G.; Dobreva, M.; Matti, V.; Beausejour, C.M.; et al. Telomeric DNA damage is irreparable and causes persistent DNA-damage-response activation. Nat. Cell Biol. 2012, 14, 355-365. [CrossRef]

106. Coluzzi, E.; Colamartino, M.; Cozzi, R.; Leone, S.; Meneghini, C.; O'Callaghan, N.; Sgura, A. Oxidative stress induces persistent telomeric DNA damage responsible for nuclear morphology change in mammalian cells. PLoS ONE 2014, 9, e110963. [CrossRef]

107. Aitken, M.L.; Dugowson, C.; Schmidt, R.A.; Fer, M. Bleomycin-induced pulmonary fibrosis in a patient with rheumatoid arthritis A possible synergistic effect? West. J. Med. 1989, 150, 344-346.

108. Santrach, P.J.; Askin, F.B.; Wells, R.J.; Azizkhan, R.G.; Merten, D.F. Nodular form of bleomycin-related pulmonary injury in patients with osteogenic sarcoma. Cancer 1989, 64, 806-811. [CrossRef]

109. Parfrey, H.; Babar, J.; Fiddler, C.A.; Chilvers, E.R. Idiopathic pulmonary fibrosis in a Christmas Island nuclear test veteran. BMJ Case Rep. 2010, 2010, bcr0620103102. [CrossRef]

110. Desai, M.Y.; Karunakaravel, K.; Wu, W.; Agarwal, S.; Smedira, N.G.; Lytle, B.W.; Griffin, B.P. Pulmonary fibrosis on multidetector computed tomography and mortality in patients with radiation-associated cardiac disease undergoing cardiac surgery. J. Thorac. Cardiovasc. Surg. 2014, 148, 475-481.e3. [CrossRef]

111. Gross, N.J. Pulmonary effects of radiation therapy. Ann. Intern. Med. 1977, 86, 81-92. [CrossRef] [PubMed]

112. Chung, K.P.; Hsu, C.L.; Fan, L.C.; Huang, Z.; Bhatia, D.; Chen, Y.J.; Hisata, S.; Cho, S.J.; Nakahira, K.; Imamura, M.; et al. Mitofusins regulate lipid metabolism to mediate the development of lung fibrosis. Nat. Commun. 2019, 10, 3390. [CrossRef]

113. Anathy, V.; Lahue, K.G.; Chapman, D.G.; Chia, S.B.; Casey, D.T.; Aboushousha, R.; van der Velden, J.L.J.; Elko, E.; Hoffman, S.M.; McMillan, D.H.; et al. Reducing protein oxidation reverses lung fibrosis. Nat. Med. 2018, 24, 1128-1135. [CrossRef] [PubMed]

114. Demedts, M.; Behr, J.; Buhl, R.; Costabel, U.; Dekhuijzen, R.; Jansen, H.M.; MacNee, W.; Thomeer, M.; Wallaert, B.; Laurent, F.; et al. High-dose acetylcysteine in idiopathic pulmonary fibrosis. N. Engl. J. Med. 2005, 353, 2229-2242. [CrossRef] [PubMed]

115. Borok, Z.; Buhl, R.; Grimes, G.J.; Bokser, A.D.; Hubbard, R.C.; Holroyd, K.J.; Roum, J.H.; Czerski, D.B.; Cantin, A.M.; Crystal, R.G. Effect of glutathione aerosol on oxidant-antioxidant imbalance in idiopathic pulmonary fibrosis. Lancet 1991, 338, 215-216. [CrossRef]

116. Guan, L.L.; Kuwahara, J.; Sugiura, Y. Guanine-specific binding by bleomycin-nickel(III) complex and its reactivity for guaninequartet telomeric DNA. Biochemistry 1993, 32, 6141-6145. [CrossRef] [PubMed]

117. Povedano, J.M.; Martinez, P.; Flores, J.M.; Mulero, F.; Blasco, M.A. Mice with Pulmonary Fibrosis Driven by Telomere Dysfunction. Cell Rep. 2015, 12, 286-299. [CrossRef]

118. Cornforth, M.N.; Meyne, J.; Littlefield, L.G.; Bailey, S.M.; Moyzis, R.K. Telomere staining of human chromosomes and the mechanism of radiation-induced dicentric formation. Radiat. Res. 1989, 120, 205-212. [CrossRef] 
119. Metcalfe, J.A.; Parkhill, J.; Campbell, L.; Stacey, M.; Biggs, P.; Byrd, P.J.; Taylor, A.M. Accelerated telomere shortening in ataxia telangiectasia. Nat. Genet. 1996, 13, 350-353. [CrossRef]

120. Gorbunova, V.; Seluanov, A.; Pereira-Smith, O.M. Expression of hTERT does not prevent stress-induced senescence in normal human fibroblasts, but protects the cells from stress-induced apoptosis and necrosis. J. Biol. Chem. 2002, 24, 24. [CrossRef]

121. Petersen, S.; Saretzki, G.; von Zglinicki, T. Preferential accumulation of single-stranded regions in telomeres of human fibroblasts. Exp. Cell Res. 1998, 239, 152-160. [CrossRef] [PubMed]

122. von Zglinicki, T. Oxidative stress shortens telomeres. Trends Biochem. Sci. 2002, 27, 339-344. [CrossRef]

123. Halu, A.; Liu, S.; Baek, S.H.; Hobbs, B.D.; Hunninghake, G.M.; Cho, M.H.; Silverman, E.K.; Sharma, A. Exploring the crossphenotype network region of disease modules reveals concordant and discordant pathways between chronic obstructive pulmonary disease and idiopathic pulmonary fibrosis. Hum. Mol. Genet. 2019, 28, 2352-2364. [CrossRef]

124. Kumar, M.; Seeger, W.; Voswinckel, R. Senescence-associated secretory phenotype and its possible role in chronic obstructive pulmonary disease. Am. J. Respir. Cell Mol. Biol. 2014, 51, 323-333. [CrossRef] [PubMed]

125. Mirabello, L.; Huang, W.Y.; Wong, J.Y.; Chatterjee, N.; Reding, D.; Crawford, E.D.; De Vivo, I.; Hayes, R.B.; Savage, S.A. The association between leukocyte telomere length and cigarette smoking, dietary and physical variables, and risk of prostate cancer. Aging Cell 2009, 8, 405-413. [CrossRef]

126. Stanley, S.E.; Chen, J.J.; Podlevsky, J.D.; Alder, J.K.; Hansel, N.N.; Mathias, R.A.; Qi, X.; Rafaels, N.M.; Wise, R.A.; Silverman, E.K.; et al. Telomerase mutations in smokers with severe emphysema. J. Clin. Investig. 2015, 125, 563-570. [CrossRef]

127. Blackburn, E.H.; Epel, E.S.; Lin, J. Human telomere biology: A contributory and interactive factor in aging, disease risks, and protection. Science 2015, 350, 1193-1198. [CrossRef]

128. Aalbers, A.M.; Kajigaya, S.; van den Heuvel-Eibrink, M.M.; van der Velden, V.H.; Calado, R.T.; Young, N.S. Human telomere disease due to disruption of the CCAAT box of the TERC promoter. Blood 2012, 119, 3060-3063. [CrossRef]

129. Hao, L.Y.; Armanios, M.; Strong, M.A.; Karim, B.; Feldser, D.M.; Huso, D.; Greider, C.W. Short telomeres, even in the presence of telomerase, limit tissue renewal capacity. Cell 2005, 123, 1121-1131. [CrossRef]

130. Fogarty, P.F.; Yamaguchi, H.; Wiestner, A.; Baerlocher, G.M.; Sloand, E.; Zeng, W.S.; Read, E.J.; Lansdorp, P.M.; Young, N.S. Late presentation of dyskeratosis congenita as apparently acquired aplastic anaemia due to mutations in telomerase RNA. Lancet 2003, 362, 1628-1630. [CrossRef]

131. Cawthon, R.M.; Smith, K.R.; O'Brien, E.; Sivatchenko, A.; Kerber, R.A. Association between telomere length in blood and mortality in people aged 60 years or older. Lancet 2003, 361,393-395. [CrossRef]

132. Mitchell, J.R.; Wood, E.; Collins, K. A telomerase component is defective in the human disease dyskeratosis congenita. Nature 1999, 402, 551-555. [CrossRef] [PubMed]

133. Kadota, T.; Yoshioka, Y.; Fujita, Y.; Araya, J.; Minagawa, S.; Hara, H.; Miyamoto, A.; Suzuki, S.; Fujimori, S.; Kohno, T.; et al Extracellular Vesicles from Fibroblasts Induce Epithelial-Cell Senescence in Pulmonary Fibrosis. Am. J. Respir. Cell Mol. Biol. 2020, 63, 623-636. [CrossRef] [PubMed]

134. Khayrullin, A.; Krishnan, P.; Martinez-Nater, L.; Mendhe, B.; Fulzele, S.; Liu, Y.; Mattison, J.A.; Hamrick, M.W. Very LongChain C24:1 Ceramide Is Increased in Serum Extracellular Vesicles with Aging and Can Induce Senescence in Bone-Derived Mesenchymal Stem Cells. Cells 2019, 8, 37. [CrossRef] [PubMed]

135. Misawa, T.; Tanaka, Y.; Okada, R.; Takahashi, A. Biology of extracellular vesicles secreted from senescent cells as senescenceassociated secretory phenotype factors. Geriatr. Gerontol. Int. 2020, 20, 539-546. [CrossRef]

136. Pardo, A.; Selman, M. Lung Fibroblasts, Aging, and Idiopathic Pulmonary Fibrosis. Ann. Am. Thorac Soc. 2016, 13 (Suppl. 5), S417-S421. [CrossRef]

137. Kelley, W.J.; Zemans, R.L.; Goldstein, D.R. Cellular senescence: Friend or foe to respiratory viral infections? Eur. Respir. J. 2020, 56, 2002708. [CrossRef]

138. Ley, B.; Newton, C.A.; Arnould, I.; Elicker, B.M.; Henry, T.S.; Vittinghoff, E.; Golden, J.A.; Jones, K.D.; Batra, K.; Torrealba, J.; et al. The MUC5B promoter polymorphism and telomere length in patients with chronic hypersensitivity pneumonitis: An observational cohort-control study. Lancet Respir. Med. 2017, 5, 639-647. [CrossRef]

139. Blackburn, E.H.; Gall, J.G. A tandemly repeated sequence at the termini of the extrachromosomal ribosomal RNA genes in Tetrahymena. J. Mol. Biol. 1978, 120, 33-53. [CrossRef]

140. Shampay, J.; Szostak, J.W.; Blackburn, E.H. DNA sequences of telomeres maintained in yeast. Nature 1984, 310, 154-157. [CrossRef]

141. Greider, C.W.; Blackburn, E.H. Identification of a specific telomere terminal transferase enzyme with two kinds of primer specificity. Cell 1985, 51, 405-413. [CrossRef]

142. de Lange, T.; Shiue, L.; Myers, R.M.; Cox, D.R.; Naylor, S.L.; Killery, A.M.; Varmus, H.E. Structure and variability of human chromosome ends. Mol. Cell. Biol. 1990, 10, 518-527. [PubMed]

143. de Lange, T. Shelterin: The protein complex that shapes and safeguards human telomeres. Genes Dev. 2005, 19, 2100-2110. [CrossRef] [PubMed]

144. de Lange, T. Shelterin-Mediated Telomere Protection. Annu. Rev. Genet. 2018, 52, 223-247. [CrossRef] [PubMed]

145. Harley, C.B.; Futcher, A.B.; Greider, C.W. Telomeres shorten during ageing of human fibroblasts. Nature 1990, 345, 458-460. [CrossRef] [PubMed]

146. Hastie, N.D.; Dempster, M.; Dunlop, M.G.; Thompson, A.M.; Green, D.K.; Allshire, R.C. Telomere reduction in human colorectal carcinoma and with ageing. Nature 1990, 346, 866-868. [CrossRef] 
147. Oexle, K.; Zwirner, A. Advanced telomere shortening in respiratory chain disorders. Hum. Mol. Genet. 1997, 6, 905-908. [CrossRef]

148. Vaziri, H.; West, M.D.; Allsopp, R.C.; Davison, T.S.; Wu, Y.S.; Arrowsmith, C.H.; Poirier, G.G.; Benchimol, S. ATM-dependent telomere loss in aging human diploid fibroblasts and DNA damage lead to the post-translational activation of p53 protein involving poly(ADP-ribose) polymerase. EMBO J. 1997, 16, 6018-6033. [CrossRef]

149. Bayne, S.; Li, H.; Jones, M.E.; Pinto, A.R.; van Sinderen, M.; Drummond, A.; Simpson, E.R.; Liu, J.P. Estrogen deficiency reversibly induces telomere shortening in mouse granulosa cells and ovarian aging In Vivo. Protein Cell 2011, 2, 333-346. [CrossRef]

150. Bayne, S.; Jones, M.E.; Li, H.; Pinto, A.R.; Simpson, E.R.; Liu, J.P. Estrogen deficiency leads to telomerase inhibition, telomere shortening and reduced cell proliferation in the adrenal gland of mice. Cell Res. 2008, 18, 1141-1150. [CrossRef]

151. Greider, C.W. Telomeres, telomerase and senescence. BioEssays News Rev. Mol. Cell. Dev. Biol. 1990, 12, 363-368. [CrossRef] [PubMed]

152. Greider, C.W. Telomeres and senescence: The history, the experiment, the future. Curr. Biol. CB 1998, 8, 178-181. [CrossRef]

153. Xie, Z.; Jay, K.A.; Smith, D.L.; Zhang, Y.; Liu, Z.; Zheng, J.; Tian, R.; Li, H.; Blackburn, E.H. Early telomerase inactivation accelerates aging independently of telomere length. Cell 2015, 160, 928-939. [CrossRef] [PubMed]

154. Karlseder, J.; Smogorzewska, A.; de Lange, T. Senescence induced by altered telomere state, not telomere loss. Science 2002, 295, 2446-2449. [CrossRef]

155. Denchi, E.L.; de Lange, T. Protection of telomeres through independent control of ATM and ATR by TRF2 and POT1. Nature 2007, 448, 1068-1071. [CrossRef]

156. d'Adda di Fagagna, F.; Reaper, P.M.; Clay-Farrace, L.; Fiegler, H.; Carr, P.; Von Zglinicki, T.; Saretzki, G.; Carter, N.P.; Jackson, S.P. A DNA damage checkpoint response in telomere-initiated senescence. Nature 2003, 426, 194-198. [CrossRef] [PubMed]

157. Deng, Y.; Guo, X.; Ferguson, D.O.; Chang, S. Multiple roles for MRE11 at uncapped telomeres. Nature 2009, 460, 914-918. [CrossRef]

158. Povedano, J.M.; Martinez, P.; Serrano, R.; Tejera, A.; Gomez-Lopez, G.; Bobadilla, M.; Flores, J.M.; Bosch, F.; Blasco, M.A. Therapeutic effects of telomerase in mice with pulmonary fibrosis induced by damage to the lungs and short telomeres. eLife 2018, 7, e31299. [CrossRef]

159. Xin, H.; Liu, D.; Wan, M.; Safari, A.; Kim, H.; Sun, W.; O'Connor, M.S.; Songyang, Z. TPP1 is a homologue of ciliate TEBP-beta and interacts with POT1 to recruit telomerase. Nature 2007, 445, 559-562. [CrossRef]

160. Wang, F.; Podell, E.R.; Zaug, A.J.; Yang, Y.; Baciu, P.; Cech, T.R.; Lei, M. The POT1-TPP1 telomere complex is a telomerase processivity factor. Nature 2007, 445, 506-510. [CrossRef]

161. Miyoshi, T.; Kanoh, J.; Saito, M.; Ishikawa, F. Fission yeast Pot1-Tpp1 protects telomeres and regulates telomere length. Science 2008, 320, 1341-1344. [CrossRef] [PubMed]

162. Zhong, F.L.; Batista, L.F.; Freund, A.; Pech, M.F.; Venteicher, A.S.; Artandi, S.E. TPP1 OB-fold domain controls telomere maintenance by recruiting telomerase to chromosome ends. Cell 2012, 150, 481-494. [CrossRef] [PubMed]

163. Nandakumar, J.; Bell, C.F.; Weidenfeld, I.; Zaug, A.J.; Leinwand, L.A.; Cech, T.R. The TEL patch of telomere protein TPP1 mediates telomerase recruitment and processivity. Nature 2012, 492, 285-289. [CrossRef] [PubMed]

164. Schmidt, J.C.; Zaug, A.J.; Cech, T.R. Live Cell Imaging Reveals the Dynamics of Telomerase Recruitment to Telomeres. Cell 2016, 166, 1188-1197.e9. [CrossRef]

165. Palm, W.; de Lange, T. How shelterin protects mammalian telomeres. Annu. Rev. Genet. 2008, 42, 301-334. [CrossRef]

166. Guo, Y.; Kartawinata, M.; Li, J.; Pickett, H.A.; Teo, J.; Kilo, T.; Barbaro, P.M.; Keating, B.; Chen, Y.; Tian, L.; et al. Inherited bone marrow failure associated with germline mutation of ACD, the gene encoding telomere protein TPP1. Blood 2014, 124, $2767-2774$. [CrossRef]

167. Kocak, H.; Ballew, B.J.; Bisht, K.; Eggebeen, R.; Hicks, B.D.; Suman, S.; O’Neil, A.; Giri, N.; Laboratory, N.D.C.G.R.; Group, N.D.C.S.W.; et al. Hoyeraal-Hreidarsson syndrome caused by a germline mutation in the TEL patch of the telomere protein TPP1 Genes Dev. 2014, 28, 2090-2102. [CrossRef]

168. Ahmad, T.; Sundar, I.K.; Tormos, A.M.; Lerner, C.A.; Gerloff, J.; Yao, H.; Rahman, I. Shelterin Telomere Protection Protein 1 Reduction Causes Telomere Attrition and Cellular Senescence via Sirtuin 1 Deacetylase in Chronic Obstructive Pulmonary Disease. Am. J. Respir. Cell Mol. Biol. 2017, 56, 38-49. [CrossRef]

169. Greider, C.W.; Blackburn, E.H. A telomeric sequence in the RNA of Tetrahymena telomerase required for telomere repeat synthesis. Nature 1989, 337, 331-337. [CrossRef]

170. Blackburn, E.H.; Greider, C.W.; Henderson, E.; Lee, M.S.; Shampay, J.; Shippen-Lentz, D. Recognition and elongation of telomeres by telomerase. Genome 1989, 31, 553-560. [CrossRef]

171. Bodnar, A.G.; Ouellette, M.; Frolkis, M.; Holt, S.E.; Chiu, C.P.; Morin, G.B.; Harley, C.B.; Shay, J.W.; Lichtsteiner, S.; Wright, W.E. Extension of life-span by introduction of telomerase into normal human cells. Science 1998, 279, 349-352. [CrossRef]

172. Harle-Bachor, C.; Boukamp, P. Telomerase activity in the regenerative basal layer of the epidermis inhuman skin and in immortal and carcinoma-derived skin keratinocytes. Proc. Natl. Acad. Sci. USA 1996, 93, 6476-6481. [CrossRef]

173. Counter, C.M.; Hahn, W.C.; Wei, W.; Caddle, S.D.; Beijersbergen, R.L.; Lansdorp, P.M.; Sedivy, J.M.; Weinberg, R.A. Dissociation among In Vitro telomerase activity, telomere maintenance, and cellular immortalization. Proc. Natl. Acad. Sci. USA 1998, 95, 14723-14728. [CrossRef] [PubMed]

174. Lee, H.W.; Blasco, M.A.; Gottlieb, G.J.; Horner, J.W., 2nd; Greider, C.W.; DePinho, R.A. Essential role of mouse telomerase in highly proliferative organs. Nature 1998, 392, 569-574. [CrossRef] [PubMed] 
175. Collins, K. Mammalian telomeres and telomerase. Curr. Opin. Cell Biol. 2000, 12, 378-383. [CrossRef]

176. Mitchell, J.R.; Collins, K. Human telomerase activation requires two independent interactions between telomerase RNA and telomerase reverse transcriptase. Mol. Cell 2000, 6, 361-371. [CrossRef]

177. Maida, Y.; Yasukawa, M.; Furuuchi, M.; Lassmann, T.; Possemato, R.; Okamoto, N.; Kasim, V.; Hayashizaki, Y.; Hahn, W.C.; Masutomi, K. An RNA-dependent RNA polymerase formed by TERT and the RMRP RNA. Nature 2009, 461, 230-235. [CrossRef]

178. Maida, Y.; Yasukawa, M.; Masutomi, K. De Novo RNA Synthesis by RNA-Dependent RNA Polymerase Activity of Telomerase Reverse Transcriptase. Mol. Cell. Biol. 2016, 36, 1248-1259. [CrossRef]

179. Yasukawa, M.; Ando, Y.; Yamashita, T.; Matsuda, Y.; Shoji, S.; Morioka, M.S.; Kawaji, H.; Shiozawa, K.; Machitani, M.; Abe, T.; et al. CDK1 dependent phosphorylation of hTERT contributes to cancer progression. Nat. Commun. 2020, 11, 1557. [CrossRef]

180. Rudolph, K.L.; Chang, S.; Millard, M.; Schreiber-Agus, N.; DePinho, R.A. Inhibition of experimental liver cirrhosis in mice by telomerase gene delivery. Science 2000, 287, 1253-1258. [CrossRef]

181. Lin, S.; Nascimento, E.M.; Gajera, C.R.; Chen, L.; Neuhofer, P.; Garbuzov, A.; Wang, S.; Artandi, S.E. Distributed hepatocytes expressing telomerase repopulate the liver in homeostasis and injury. Nature 2018, 556, 244-248. [CrossRef] [PubMed]

182. Nicholls, C.; Li, H.; Wang, J.Q.; Liu, J.P. Molecular regulation of telomerase activity in aging. Protein Cell 2012, 2, 726-738. [CrossRef] [PubMed]

183. Yuan, X.; Larsson, C.; Xu, D. Mechanisms underlying the activation of TERT transcription and telomerase activity in human cancer: Old actors and new players. Oncogene 2019, 38, 6172-6183. [CrossRef]

184. Xu, D.; Li, H.; Liu, J.P. Inhibition of telomerase by targeting MAP kinase signaling. Methods Mol. Biol. 2007, 405, 147-165. [CrossRef]

185. Xu, D.; Dwyer, J.; Li, H.; Duan, W.; Liu, J.P. Ets2 maintains hTERT gene expression and breast cancer cell proliferation by interacting with c-Myc. J. Biol. Chem. 2008, 283, 23567-23580. [CrossRef] [PubMed]

186. Dwyer, J.; Li, H.; Xu, D.; Liu, J.P. Transcriptional regulation of telomerase activity: Roles of the the ets transcription factor family. Ann. N. Y. Acad. Sci. 2007, 1114, 36-47. [CrossRef]

187. Dwyer, J.M.; Liu, J.P. Ets2 Transcription Factor, Telomerase Activity and Breast Cancer. Clin. Exp. Pharmacol. Physiol. 2009, 37, 83-87. [CrossRef] [PubMed]

188. Li, H.; Xu, D.; Li, J.; Berndt, M.C.; Liu, J.P. Transforming growth factor beta suppresses human telomerase reverse transcriptase (hTERT) by Smad3 interactions with c-Myc and the hTERT gene. J. Biol. Chem. 2006, 281, 25588-25600. [CrossRef]

189. Horn, S.; Figl, A.; Rachakonda, P.S.; Fischer, C.; Sucker, A.; Gast, A.; Kadel, S.; Moll, I.; Nagore, E.; Hemminki, K.; et al. TERT promoter mutations in familial and sporadic melanoma. Science 2013, 339, 959-961. [CrossRef]

190. Huang, F.W.; Hodis, E.; Xu, M.J.; Kryukov, G.V.; Chin, L.; Garraway, L.A. Highly recurrent TERT promoter mutations in human melanoma. Science 2013, 339, 957-959. [CrossRef]

191. Zhang, F.; Wang, S.; Zhu, J. ETS variant transcription factor 5 and c-Myc cooperate in derepressing the human telomerase gene promoter via composite ETS/E-box motifs. J. Biol. Chem. 2020, 295, 10062-10075. [CrossRef]

192. Wu, K.J.; Grandori, C.; Amacker, M.; Simon-Vermot, N.; Polack, A.; Lingner, J.; Dalla-Favera, R. Direct activation of TERT transcription by c-MYC. Nat. Genet. 1999, 21, 220-224. [CrossRef] [PubMed]

193. Xu, D.; Popov, N.; Hou, M.; Wang, Q.; Bjorkholm, M.; Gruber, A.; Menkel, A.R.; Henriksson, M. Switch from Myc/Max to Mad1/Max binding and decrease in histone acetylation at the telomerase reverse transcriptase promoter during differentiation of HL60 cells. Proc. Natl. Acad. Sci. USA 2001, 98, 3826-3831. [CrossRef] [PubMed]

194. Bayne, S.; Jones, M.E.; Li, H.; Liu, J.P. Potential roles for estrogen regulation of telomerase activity in aging. Ann. N. Y. Acad. Sci. 2007, 1114, 48-55. [CrossRef] [PubMed]

195. Bayne, S.; Liu, J.P. Hormones and growth factors regulate telomerase activity in ageing and cancer. Mol. Cell. Endocrinol. 2005, 240, 11-22. [CrossRef] [PubMed]

196. Liu, J.; Wang, L.; Wang, Z.; Liu, J.P. Roles of Telomere Biology in Cell Senescence, Replicative and Chronological Ageing. Cells 2019, 8, 54. [CrossRef] [PubMed]

197. Liu, N.; Ding, D.; Hao, W.; Yang, F.; Wu, X.; Wang, M.; Xu, X.; Ju, Z.; Liu, J.P.; Song, Z.; et al. hTERT promotes tumor angiogenesis by activating VEGF via interactions with the Sp1 transcription factor. Nucleic Acids Res. 2016, 44, 8693-8703. [CrossRef]

198. Liu, N.; Guo, X.H.; Liu, J.P.; Cong, Y.S. Role of telomerase in the tumour microenvironment. Clin. Exp. Pharmacol. Physiol. 2020, 47, 357-364. [CrossRef]

199. Xu, J.; Xu, X.; Jiang, L.; Dua, K.; Hansbro, P.M.; Liu, G. SARS-CoV-2 induces transcriptional signatures in human lung epithelial cells that promote lung fibrosis. Respir. Res. 2020, 21, 182. [CrossRef]

200. Wicik, Z.; Eyileten, C.; Jakubik, D.; Simoes, S.N.; Martins, D.C., Jr.; Pavao, R.; Siller-Matula, J.M.; Postula, M. ACE2 Interaction Networks in COVID-19: A Physiological Framework for Prediction of Outcome in Patients with Cardiovascular Risk Factors. J. Clin. Med. 2020, 9, 3743. [CrossRef]

201. Acosta, J.C.; Banito, A.; Wuestefeld, T.; Georgilis, A.; Janich, P.; Morton, J.P.; Athineos, D.; Kang, T.W.; Lasitschka, F.; Andrulis, M.; et al. A complex secretory program orchestrated by the inflammasome controls paracrine senescence. Nat. Cell Biol. 2013, 15, 978-990. [CrossRef] [PubMed]

202. Nieto, M.A.; Huang, R.Y.; Jackson, R.A.; Thiery, J.P. EMT: 2016. Cell 2016, 166, 21-45. [CrossRef] [PubMed]

203. Xu, Y.D.; Hua, J.; Mui, A.; O'Connor, R.; Grotendorst, G.; Khalil, N. Release of biologically active TGF-beta1 by alveolar epithelial cells results in pulmonary fibrosis. Am. J. Physiol. Lung Cell. Mol. Physiol. 2003, 285, 527-539. [CrossRef] [PubMed] 
204. Hu, B.; Liu, J.; Wu, Z.; Liu, T.; Ullenbruch, M.R.; Ding, L.; Henke, C.A.; Bitterman, P.B.; Phan, S.H. Reemergence of hedgehog mediates epithelial-mesenchymal crosstalk in pulmonary fibrosis. Am. J. Respir. Cell Mol. Biol. 2015, 52, 418-428. [CrossRef] [PubMed]

205. Degryse, A.L.; Tanjore, H.; Xu, X.C.; Polosukhin, V.V.; Jones, B.R.; Boomershine, C.S.; Ortiz, C.; Sherrill, T.P.; McMahon, F.B.; Gleaves, L.A.; et al. TGFbeta signaling in lung epithelium regulates bleomycin-induced alveolar injury and fibroblast recruitment. Am. J. Physiol. Lung Cell. Mol. Physiol. 2011, 300, 887-897. [CrossRef]

206. Zhang, T.; Zhou, J.; Yue, H.; Du, C.; Xiao, Z.; Zhao, W.; Li, N.; Wang, X.; Liu, X.; Li, Y.; et al. Glycogen synthase kinase-3beta promotes radiation-induced lung fibrosis by regulating beta-catenin/lin28 signaling network to determine type II alveolar stem cell transdifferentiation state. FASEB J. 2020, 34, 12466-12480. [CrossRef]

207. Bonniaud, P.; Kolb, M.; Galt, T.; Robertson, J.; Robbins, C.; Stampfli, M.; Lavery, C.; Margetts, P.J.; Roberts, A.B.; Gauldie, J. Smad3 null mice develop airspace enlargement and are resistant to TGF-beta-mediated pulmonary fibrosis. J. Immunol. 2004, 173, 2099-2108. [CrossRef]

208. Kang, J.H.; Jung, M.Y.; Yin, X.; Andrianifahanana, M.; Hernandez, D.M.; Leof, E.B. Cell-penetrating peptides selectively targeting SMAD3 inhibit profibrotic TGF-beta signaling. J. Clin. Investig. 2017, 127, 2541-2554. [CrossRef]

209. Cassar, L.; Li, H.; Pinto, A.R.; Nicholls, C.; Bayne, S.; Liu, J.P. Bone morphogenetic protein-7 inhibits telomerase activity, telomere maintenance, and cervical tumor growth. Cancer Res. 2008, 68, 9157-9166. [CrossRef]

210. Cassar, L.; Li, H.; Jiang, F.X.; Liu, J.P. TGF-beta induces telomerase-dependent pancreatic tumor cell cycle arrest. Mol. Cell. Endocrinol. 2010, 320, 97-105. [CrossRef]

211. Cassar, L.; Nicholls, C.; Pinto, A.R.; Chen, R.; Wang, L.; Li, H.; Liu, J.P. TGF-beta receptor mediated telomerase inhibition, telomere shortening and breast cancer cell senescence. Protein Cell 2017, 8, 39-54. [CrossRef] [PubMed]

212. Cassar, L.; Nicholls, C.; Pinto, A.R.; Li, H.; Liu, J.P. Bone morphogenetic protein-7 induces telomerase inhibition, telomere shortening, breast cancer cell senescence, and death via Smad3. FASEB J. 2009, 23, 1880-1892. [CrossRef] [PubMed]

213. Wang, L.; Wang, Z.; Liu, J.P. Identification of peptidomimetic telomere dysfunction inhibitor (TELODIN) through telomere dysfunction-induced foci (TIF) assay. STAR Protoc. 2021, 2, 100620. [CrossRef]

214. Prowse, K.R.; Greider, C.W. Developmental and tissue-specific regulation of mouse telomerase and telomere length. Proc. Natl. Acad. Sci. USA 1995, 92, 4818-4822. [CrossRef]

215. Davis, R.J.; Welcker, M.; Clurman, B.E. Tumor suppression by the Fbw7 ubiquitin ligase: Mechanisms and opportunities. Cancer Cell 2014, 26, 455-464. [CrossRef] [PubMed]

216. Gallo, L.H.; Ko, J.; Donoghue, D.J. The importance of regulatory ubiquitination in cancer and metastasis. Cell Cycle 2017, 16, 634-648. [CrossRef] [PubMed]

217. Chang, J.; Wang, Y.; Shao, L.; Laberge, R.M.; Demaria, M.; Campisi, J.; Janakiraman, K.; Sharpless, N.E.; Ding, S.; Feng, W.; et al Clearance of senescent cells by ABT263 rejuvenates aged hematopoietic stem cells in mice. Nat. Med. 2016, 22, 78-83. [CrossRef]

218. Yosef, R.; Pilpel, N.; Tokarsky-Amiel, R.; Biran, A.; Ovadya, Y.; Cohen, S.; Vadai, E.; Dassa, L.; Shahar, E.; Condiotti, R.; et al. Directed elimination of senescent cells by inhibition of BCL-W and BCL-XL. Nat. Commun 2016, 7, 11190. [CrossRef]

219. Schafer, M.J.; White, T.A.; Iijima, K.; Haak, A.J.; Ligresti, G.; Atkinson, E.J.; Oberg, A.L.; Birch, J.; Salmonowicz, H.; Zhu, Y.; et al Cellular senescence mediates fibrotic pulmonary disease. Nat. Commun. 2017, 8, 14532. [CrossRef]

220. Ogrodnik, M.; Zhu, Y.; Langhi, L.G.P.; Tchkonia, T.; Kruger, P.; Fielder, E.; Victorelli, S.; Ruswhandi, R.A.; Giorgadze, N.; Pirtskhalava, T.; et al. Obesity-Induced Cellular Senescence Drives Anxiety and Impairs Neurogenesis. Cell Metab. 2019, 29, 1061-1077.e8. [CrossRef]

221. Baker, D.J.; Childs, B.G.; Durik, M.; Wijers, M.E.; Sieben, C.J.; Zhong, J.; Saltness, R.A.; Jeganathan, K.B.; Verzosa, G.C.; Pezeshki, A.; et al. Naturally occurring p16(Ink4a)-positive cells shorten healthy lifespan. Nature 2016, 530, 184-189. [CrossRef] [PubMed]

222. Jeon, O.H.; Kim, C.; Laberge, R.M.; Demaria, M.; Rathod, S.; Vasserot, A.P.; Chung, J.W.; Kim, D.H.; Poon, Y.; David, N.; et al. Local clearance of senescent cells attenuates the development of post-traumatic osteoarthritis and creates a pro-regenerative environment. Nat. Med. 2017, 23, 775-781. [CrossRef] [PubMed]

223. Baar, M.P.; Brandt, R.M.C.; Putavet, D.A.; Klein, J.D.D.; Derks, K.W.J.; Bourgeois, B.R.M.; Stryeck, S.; Rijksen, Y.; van Willigenburg, H.; Feijtel, D.A.; et al. Targeted Apoptosis of Senescent Cells Restores Tissue Homeostasis in Response to Chemotoxicity and Aging. Cell 2017, 169, 132-147.e16. [CrossRef] [PubMed]

224. Zhu, Y.; Doornebal, E.J.; Pirtskhalava, T.; Giorgadze, N.; Wentworth, M.; Fuhrmann-Stroissnigg, H.; Niedernhofer, L.J.; Robbins, P.D.; Tchkonia, T.; Kirkland, J.L. New agents that target senescent cells: The flavone, fisetin, and the BCL-XL inhibitors, A1331852 and A1155463. Aging 2017, 9, 955-963. [CrossRef]

225. He, Y.; Li, W.; Lv, D.; Zhang, X.; Zhang, X.; Ortiz, Y.T.; Budamagunta, V.; Campisi, J.; Zheng, G.; Zhou, D. Inhibition of USP7 activity selectively eliminates senescent cells in part via restoration of p53 activity. Aging Cell 2020, 19, e13117. [CrossRef]

226. Weber, L. Patented inhibitors of p53-Mdm2 interaction (2006-2008). Expert Opin. Ther. Pat. 2010, 20, 179-191. [CrossRef]

227. Fuhrmann-Stroissnigg, H.; Ling, Y.Y.; Zhao, J.; McGowan, S.J.; Zhu, Y.; Brooks, R.W.; Grassi, D.; Gregg, S.Q.; Stripay, J.L.; Dorronsoro, A.; et al. Identification of HSP90 inhibitors as a novel class of senolytics. Nat. Commun. 2017, 8, 422. [CrossRef]

228. Miyata, Y. Hsp90 inhibitor geldanamycin and its derivatives as novel cancer chemotherapeutic agents. Curr. Pharm. Des. 2005, 11, 1131-1138. [CrossRef]

229. Cherif, H.; Bisson, D.G.; Jarzem, P.; Weber, M.; Ouellet, J.A.; Haglund, L. Curcumin and o-Vanillin Exhibit Evidence of Senolytic Activity in Human IVD Cells In Vitro. J. Clin. Med. 2019, 8, 433. [CrossRef] 
230. Li, W.; He, Y.; Zhang, R.; Zheng, G.; Zhou, D. The curcumin analog EF24 is a novel senolytic agent. Aging 2019, 11, 771-782. [CrossRef]

231. Wang, Y.; Chang, J.; Liu, X.; Zhang, X.; Zhang, S.; Zhang, X.; Zhou, D.; Zheng, G. Discovery of piperlongumine as a potential novel lead for the development of senolytic agents. Aging 2016, 8, 2915-2926. [CrossRef]

232. Yang, D.; Tian, X.; Ye, Y.; Liang, Y.; Zhao, J.; Wu, T.; Lu, N. Identification of GL-V9 as a novel senolytic agent against senescent breast cancer cells. Life Sci. 2021, 272, 119196. [CrossRef] [PubMed]

233. Guerrero, A.; Herranz, N.; Sun, B.; Wagner, V.; Gallage, S.; Guiho, R.; Wolter, K.; Pombo, J.; Irvine, E.E.; Innes, A.J.; et al. Cardiac glycosides are broad-spectrum senolytics. Nat. Metab 2019, 1, 1074-1088. [CrossRef]

234. Triana-Martinez, F.; Picallos-Rabina, P.; Da Silva-Alvarez, S.; Pietrocola, F.; Llanos, S.; Rodilla, V.; Soprano, E.; Pedrosa, P.; Ferreiros, A.; Barradas, M.; et al. Identification and characterization of Cardiac Glycosides as senolytic compounds. Nat. Commun. 2019, 10, 4731. [CrossRef] [PubMed]

235. Gonzalez-Gualda, E.; Paez-Ribes, M.; Lozano-Torres, B.; Macias, D.; Wilson, J.R., 3rd; Gonzalez-Lopez, C.; Ou, H.L.; MironBarroso, S.; Zhang, Z.; Lerida-Viso, A.; et al. Galacto-conjugation of Navitoclax as an efficient strategy to increase senolytic specificity and reduce platelet toxicity. Aging Cell 2020, 19, e13142. [CrossRef]

236. Cai, Y.; Zhou, H.; Zhu, Y.; Sun, Q.; Ji, Y.; Xue, A.; Wang, Y.; Chen, W.; Yu, X.; Wang, L.; et al. Elimination of senescent cells by beta-galactosidase-targeted prodrug attenuates inflammation and restores physical function in aged mice. Cell Res. 2020, 30, 574-589. [CrossRef] [PubMed]

237. Guerrero, A.; Guiho, R.; Herranz, N.; Uren, A.; Withers, D.J.; Martinez-Barbera, J.P.; Tietze, L.F.; Gil, J. Galactose-modified duocarmycin prodrugs as senolytics. Aging Cell 2020, 19, e13133. [CrossRef] [PubMed]

238. He, Y.; Zhang, X.; Chang, J.; Kim, H.N.; Zhang, P.; Wang, Y.; Khan, S.; Liu, X.; Zhang, X.; Lv, D.; et al. Using proteolysis-targeting chimera technology to reduce navitoclax platelet toxicity and improve its senolytic activity. Nat. Commun. 2020, 11, 1996. [CrossRef]

239. Wakita, M.; Takahashi, A.; Sano, O.; Loo, T.M.; Imai, Y.; Narukawa, M.; Iwata, H.; Matsudaira, T.; Kawamoto, S.; Ohtani, N.; et al. A BET family protein degrader provokes senolysis by targeting NHEJ and autophagy in senescent cells. Nat. Commun. 2020, 11, 1935. [CrossRef] [PubMed]

240. Nogueira-Recalde, U.; Lorenzo-Gomez, I.; Blanco, F.J.; Loza, M.I.; Grassi, D.; Shirinsky, V.; Shirinsky, I.; Lotz, M.; Robbins, P.D.; Dominguez, E.; et al. Fibrates as drugs with senolytic and autophagic activity for osteoarthritis therapy. EBioMedicine 2019, 45, 588-605. [CrossRef]

241. Ozsvari, B.; Nuttall, J.R.; Sotgia, F.; Lisanti, M.P. Azithromycin and Roxithromycin define a new family of "senolytic" drugs that target senescent human fibroblasts. Aging 2018, 10, 3294-3307. [CrossRef] [PubMed]

242. Cho, H.J.; Yang, E.J.; Park, J.T.; Kim, J.R.; Kim, E.C.; Jung, K.J.; Park, S.C.; Lee, Y.S. Identification of SYK inhibitor, R406 as a novel senolytic agent. Aging 2020, 12, 8221-8240. [CrossRef] [PubMed]

243. Demidenko, Z.N.; Zubova, S.G.; Bukreeva, E.I.; Pospelov, V.A.; Pospelova, T.V.; Blagosklonny, M.V. Rapamycin decelerates cellular senescence. Cell Cycle 2009, 8, 1888-1895. [CrossRef] [PubMed]

244. Hubackova, S.; Davidova, E.; Rohlenova, K.; Stursa, J.; Werner, L.; Andera, L.; Dong, L.; Terp, M.G.; Hodny, Z.; Ditzel, H.J.; et al Selective elimination of senescent cells by mitochondrial targeting is regulated by ANT2. Cell Death Differ. 2019, 26, 276-290. [CrossRef]

245. Moiseeva, O.; Deschenes-Simard, X.; St-Germain, E.; Igelmann, S.; Huot, G.; Cadar, A.E.; Bourdeau, V.; Pollak, M.N.; Ferbeyre, G. Metformin inhibits the senescence-associated secretory phenotype by interfering with IKK/NF-kappaB activation. Aging Cell 2013, 12, 489-498. [CrossRef]

246. Peilin, W.; Songsong, T.; Chengyu, Z.; Zhi, C.; Chunhui, M.; Yinxian, Y.; Lei, Z.; Min, M.; Zongyi, W.; Mengkai, Y.; et al. Directed elimination of senescent cells attenuates development of osteoarthritis by inhibition of c-IAP and XIAP. Biochim. Biophys. Acta Mol. Basis Dis. 2019, 1865, 2618-2632. [CrossRef]

247. Samaraweera, L.; Adomako, A.; Rodriguez-Gabin, A.; McDaid, H.M. A Novel Indication for Panobinostat as a Senolytic Drug in NSCLC and HNSCC. Sci. Rep. 2017, 7, 1900. [CrossRef] 